British Journal of Medicine \& Medical Research

17(2): 1-30, 2016, Article no.BJMMR.27208

ISSN: 2231-0614, NLM ID: 101570965

SCIENCEDOMAIN international

www.sciencedomain.org

\title{
Quantifying Resistance to Sliding in Orthodontics: A Systematic Review
}

\author{
Hamza Tageldin ${ }^{1}$, Maria Cadenas de Llano-Pérula ${ }^{1}$, Patrick Thevissen ${ }^{2}$, \\ Jean-Pierre Celis ${ }^{3,4}$ and Guy Willems ${ }^{1,}$ \\ ${ }^{1}$ Department of Oral Health Sciences-Orthodontics, KU Leuven and Dentistry, University Hospital \\ Leuven, 3000 Leuven, Belgium. \\ ${ }^{2}$ Department of Oral Health Sciences-Forensic Dentistry, KU Leuven and Dentistry, University \\ Hospital Leuven, 3000 Leuven, Belgium. \\ ${ }^{3}$ Department of Materials Engineering (MTM), Faculty of Engineering, University of KU Leuven, \\ 3000 Leuven, Belgium. \\ ${ }^{4}$ Falex Tribology N.V., Wingepark 23B, 3110 Rotselaar, Belgium.
}

\begin{abstract}
Authors' contributions
This work was carried out in collaboration between all authors. Authors HT, PT and GW designed the study. Data collection, reviewing of the collected studies and writing the first draft of the manuscript were performed by author HT. Additional reviewing and cross checking of findings were performed by the authors MCLP and GW. Mechanical and material-related aspects were checked by author JPC. All authors read and approved the final manuscript.

Article Information

DOI: 10.9734/BJMMR/2016/27208 Editor(s):

(1) Emad Tawfik Mahmoud Daif, Professor of Oral and Maxillofacial Surgery, Cairo University, Egypt. Reviewers:

(1) Reji Abraham, Sri Hasanamba Dental College, Hassan, Karnataka, India. (2) Fellah Mamoun, Khenchela University, Algeria.

(3) F. Armando Montesinos, National Autonomous University of Mexico, Mexico. (4) Yara Mahfouz, Arab American University, Jenin, Palestine, Saudi Arabia. Complete Peer review History: http://www.sciencedomain.org/review-history/15531
\end{abstract}

Review Article

Received $23^{\text {rd }}$ May 2016

Accepted $15^{\text {th }}$ July 2016

Published 26 ${ }^{\text {th }}$ July 2016

\section{ABSTRACT}

Objective: The present article aims to review all the in vitro experimental setups available in literature used to evaluate the resistance to sliding (RS) in orthodontics in correlation with other related parameters.

Methods: An electronic search was performed in three different data bases including all articles published until $20^{\text {th }}$ February 2016. Additionally, a manual search through the reference lists of the collected records was performed. Studies that addressed different experimental setups to evaluate RS were selected, reviewed, and grouped per research group. The experimental setups were 
compared and assessed based on their degree of clinical simulation.

Results: A total of 1380 non-duplicate records were primarily selected in the electronic search. After applying the selection criteria, only 189 studies were considered eligible.

Conclusion: The clinical simulation of each setup varied based on the aim of the performed investigation. None of the included experimental setups could achieve a full clinical simulation by studying several variables synergistically in a scenario as similar as possible to the oral environment.

Clinical Relevance: Unfortunately, in vivo evaluation of RS is not possible so far. Therefore, reviewing the in vitro methods and analyzing them on the light of the clinical situations they represent, would be of a great clinical benefit. Deeper understanding of this multifactorial phenomenon will help improving the current in vitro designs with an obvious clinical impact.

Keywords: Experimental design; friction; resistance to sliding; in vitro techniques; orthodontics; systematic review.

\section{INTRODUCTION}

The lowering of the resistance to sliding (RS) in contemporary orthodontics is a matter of interest when introducing new materials. However, RS is determined by many variables, such as biological parameters (saliva, plaque, pellicle, tissue response, etc.), mechanical characteristics (i.e. angulation, degree of malocclusion, etc.) as well as physical and chemical material properties [1]. Many investigations have been carried out over the past decades to evaluate the friction generated between brackets and archwires in correlation with these variables [2-8]. However, they actually reported RS, which is not interchangeable with the term "friction". So, it is important to differentiate between the two terms. From a mechanical point of view, friction is defined as "the resistance to motion during sliding or rolling that is experienced when one solid body moves tangentially over another with which it is in contact" [9]. RS is a more comprehensive concept than friction as it includes other components that resist sliding such as binding and notching [10].

Evaluation of the influence of each of the parameters involved in RS separately is not feasible in vivo since the RS is a multi-factorial process $[1,11]$. Moreover, a full in vitro clinical simulation has not been accomplished so far, presumably because of its technical difficulty. Such capabilities would allow a high standard of basic hypothesis testing, product development, quality control, and product performance evaluation with relative ease [12]. For these reasons, there have been many in vitro experimental trials to simulate certain clinical scenarios. The degree of clinical simulation has varied depending upon the purpose of each investigation, i.e. the desired clinical simulation and the available capabilities.

\subsection{Objectives}

The purpose of this study is to review all the experimental in vitro setups reported in literature for the evaluation of RS of orthodontic materials and the investigation of their capabilities and degree of clinical simulation in order to answer the following research question: What is the most ideal or controlled way to quantify resistance to sliding in orthodontics taking into account the various clinical conditions?

\section{MATERIALS AND METHODS}

\subsection{Protocol}

A systematic review structure has been followed, whose protocol was developed prior to the start. The reporting of this review follows the PRISMA guidelines (www.prisma-statement.org) [13].

\subsection{Information Sources and Search Strategy}

An electronic search was performed in three different data bases, namely The MedLine Database (Entrez PubMed, www.ncbi.nim.nih.gov), Web of Science (Inspec Database, apps.webofknowledge.com), and Grey Literature Report of the New York Academy of Medicine (www.greylit.org). The search included all studies published in literature until February the $20^{\text {th }}$ 2016. No language restrictions were taken into account. A search string of keywords was developed based on the terms "friction" and "orthodontics" which are the most commonly used keywords in the studies of interest. Other keywords related to the aim of this review were also included in the search string, such as "in vitro", "test" or "technique" (Table 1). 
Table 1. Electronic search string details

\begin{tabular}{ll}
\hline Data Base & $\begin{array}{l}\text { Keywords } \\
\text { (search strategy) }\end{array}$ \\
\hline Pubmed & (Orthodontic[all fields] OR ("orthodontics"[MeSH \\
From inception until 20 & Terms] OR "orthodontics"[all fields])) AND \\
& $\begin{array}{l}\text { (Friction[all fields] OR Frictional[all fields] OR } \\
\text { Resistance[all fields]) AND ((In vitro[all fields]) OR } \\
\text { (Technique[all fields]) OR (model[all fields]) OR }\end{array}$ \\
& (study[all field]) OR (test[all fields])) \\
\hline Web of Science (Inspec) & $\begin{array}{l}\text { TS=(Orthodontic OR Orthodontics) AND } \\
\text { TS=(Friction OR Frictional OR resistance) OR } \\
\text { From inception until 20 }\end{array}$ \\
\hline Grey Literature Report & CL=(A0600) \\
\hline From inception until $20^{\text {th }}$ of February 2016 & Friction AND/OR Orthodontics \\
\hline
\end{tabular}

\subsection{Eligibility and Study Selection}

The inclusion and exclusion criteria listed in Table 2 were established according to the PICO format as follows:

- Problem: RS could not be evaluated in vivo so far, and the high number and variability of the in vitro studies make it difficult to clearly state how these in vitro methods are related to the clinical background in order to fully understand RS.

- Intervention: reviewing all experimental designs published in literature.

- Comparison of the reviewed designs in terms of capabilities, limitations and degree of clinical simulation.

- Outcome: improving the knowledge of the limitations and capabilities of the current designs. Being aware of the shortages of experimental designs helps to develop an improved, more clinically oriented model that could result in a better understanding of RS.

The initial study selection was based on titles and abstracts. Next, the reference lists of the selected studies were additionally checked manually. Then, all the selected studies were read in full text to verify their suitability. Based on the full-text reading, they were grouped per research groups, and checked for the experimental setup used and the testing conditions. From the same research group, only the first paper describing the experimental setup was selected, while the remaining papers were selected only if they described different testing conditions. The collection of data and reviewing of the collected studies were performed by the first author. Additional reviewing and cross checking of findings were performed by the second and the corresponding authors independently.

\subsection{Setup Evaluation and Data Collection Process}

The studies included in this review were grouped according to the experimental setup used. Different research groups using similar experimental setups were grouped together with the first research group describing that setup, and they were collected under the term "others" in Appendices I and II. In case that more than one setup was developed by the same research group, they were marked by Latin numbers in Appendices I and II. After that, every research group was subjected to a developed methodology assessment questionnaire (Table 3). That questionnaire consisted of "Yes" and "No" questions, each of them describes a clinical scenario or a criterion. "Yes" indicated that the criterion could be performed by the setup, while "No" indicated that the criterion could not be performed by the setup or the information was not reported. The scoring of results is as follows: "Yes" = 1 points and "No" $=0$ points. Based on the questionnaire, a score was given to each setup which indicated the degree of clinical simulation achieved with that experimental setup (Appendix I). The data of different testing conditions in each research group were extracted and piloted to provide a more comprehensive overview on the different methodologies (Appendix II). 
Table 2. Eligibility selection criteria

\begin{tabular}{|c|c|}
\hline Inclusion criteria & Exclusion criteria \\
\hline $\begin{array}{l}\text { 1-Studies considering and/or quantifying } \\
\text { friction in orthodontic tooth movement using } \\
\text { bracket/archwire system under different } \\
\text { conditions. } \\
\text { 2-Studies evaluating aspects possibly } \\
\text { affected by friction } \\
\text { 3-Studies evaluating material and } \\
\text { mechanical properties possibly affecting } \\
\text { friction. }\end{array}$ & $\begin{array}{l}\text { 1-Editorial letters, opinions, comments and reviews. } \\
\text { 2-Studies considering frictional properties not } \\
\text { related to orthodontics. } \\
\text { 3-Studies related to orthodontics but not related to } \\
\text { frictional properties. } \\
\text { 4-Studies considering other orthodontic treatment } \\
\text { modalities. } \\
\text { 5-Studies considering other forces not in the context } \\
\text { of RS (e.g. Interdental or occlusal forces). } \\
6 \text {-Studies considering biologic effects of materials } \\
\text { used in orthodontics. }\end{array}$ \\
\hline
\end{tabular}

Table 3. Methodology assessment protocol

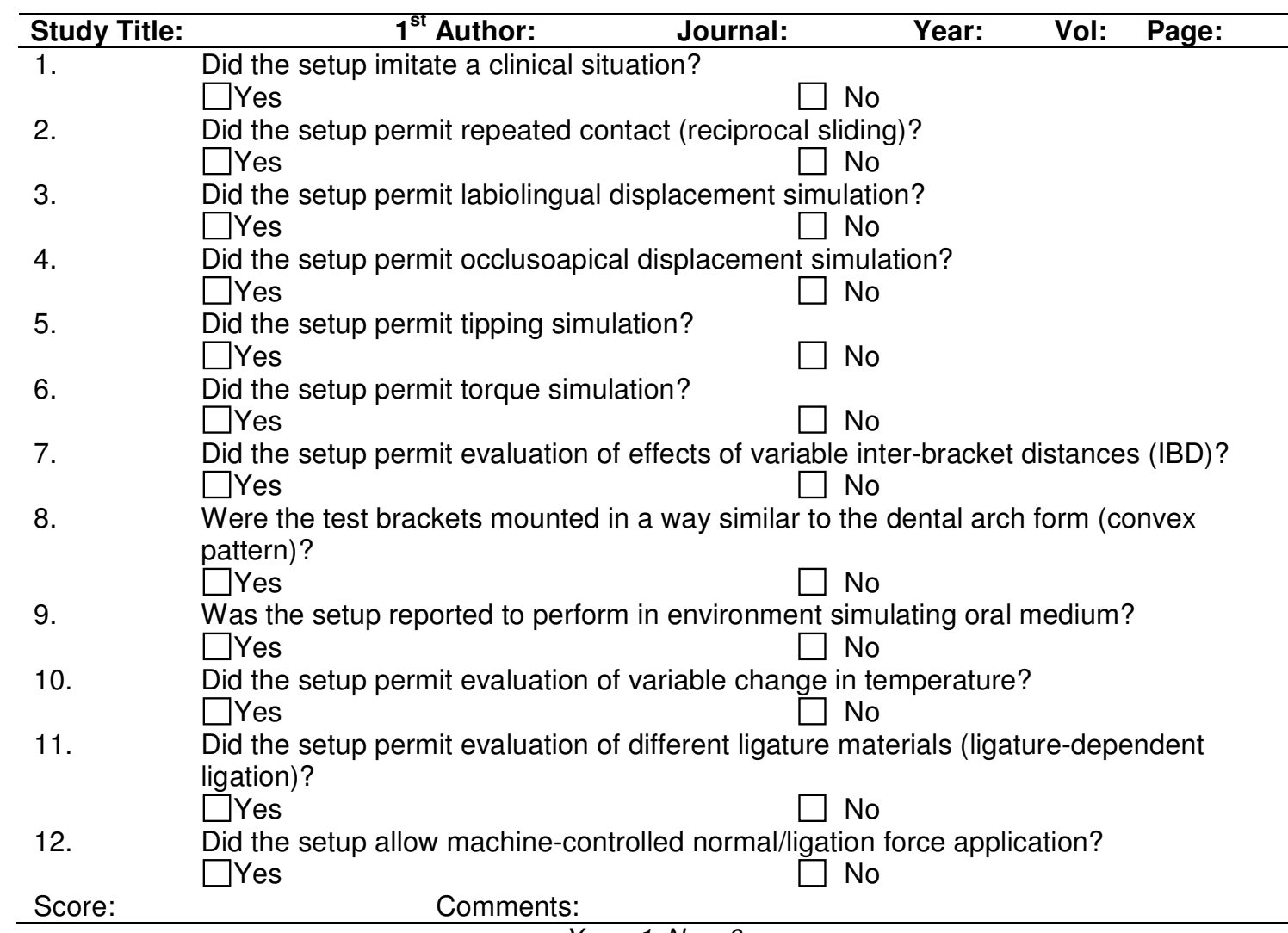

$$
Y e s=1, N o=0
$$

\section{RESULTS}

\subsection{Study Selection and Study Characteristics}

A general overview of the performed electronic search and study selection is shown in a flow diagram following the PRISMA guidelines [13] (www.prisma-statement.org) (Fig. 1). The initial search retrieved 1,416 records from all data bases (1,162 PubMed, 254 Inspec, 0 Grey Literature Report). Once duplicates were removed, 1,380 records were screened. By checking manually the reference lists of the included studies, a total of 15 records was further included. 1,005 records were excluded for not matching the aim of this review. 390 study were read in full, from which 200 study were excluded for not matching the selection criteria listed in Table 2. One additional non- 
English study was further excluded for the inability to translate the text $(n=201)$. We contacted the authors for help but we got no response [14]. A total of 189 studies were considered eligible and finally included in this review.

\subsection{Setup Evaluation and Study Characteristics}

From the 189 studies, 98 groups were identified, each of them representing a different experimental setup. However, there is no clear cut among the experimental setups. Details of methodological score results of every setup are shown in Appendix I, while the details of different testing conditions are shown in Appendix II. Scoring varied based on the degree of clinical simulation achieved by every setup. The higher the score, the more clinical scenarios could be achieved by a given setup, and the closer it will be to the in vivo state. None of the setups included in this review achieved a score higher than 7 out of 12 . The highest score was achieved by the setup developed by Kusy research group [5,15-17] (Appendix I). In their setup, a singlepass, straight-line traction was used to slide an archwire relative to a single test bracket between two movable rollers simulating different interbracket distances (IBDs) under various amounts of static tipping. Their system allowed either wet or dry interface testing under thermocouple controlled temperature. On the other hand, the lowest score of 1 was given to the setup developed by Major research group [18] (Appendix I), as insufficient information was reported about the full capabilities of that setup. In their setup, a Teflon guide applied a load of $500 \mathrm{~g}$ on the test wire which was pulled over either lateral or inter-wing surfaces of the test bracket (single surface contact interface). Their tests were performed under dry conditions and no information was reported on other media simulation and/or temperature control.

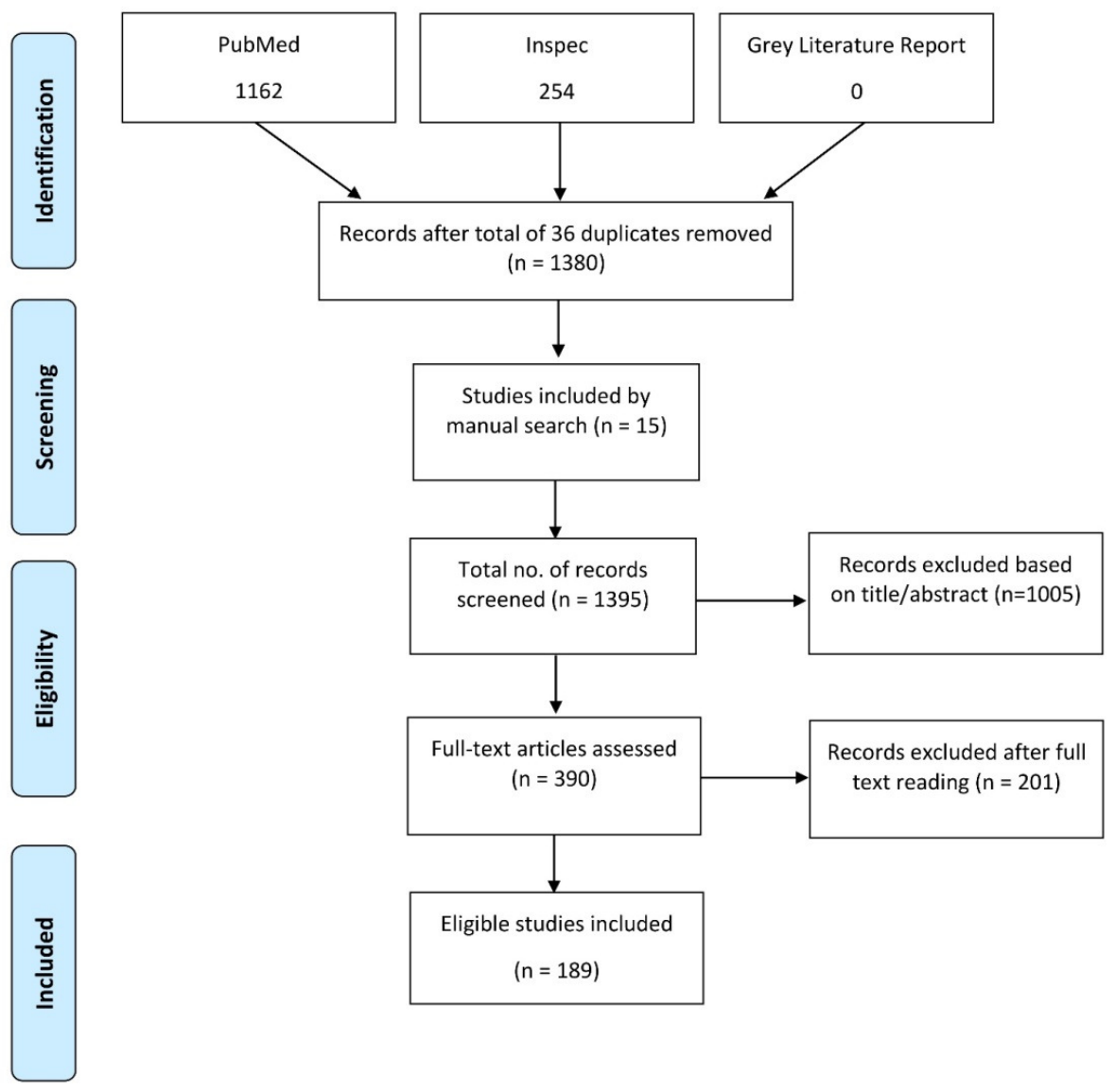

Fig. 1. Illustrative PRISMA diagram flow 
None of the reviewed in vitro studies was able to fully replicate several clinical conditions at the same time. The testing conditions varied based on the research groups and the desired clinical simulations. The counter-bodies used in the setups were either brackets [19-21], flats [22] or disks [23]. The ligation force was mostly ligaturedependent [24-26], and an average of $200 \mathrm{~g}$ force was applied. Tipping ranged from $0^{\circ}$ to $13^{\circ}$ [5], while other displacements, such as apical or labial, ranged from 0 to $4 \mathrm{~mm}[27,28]$. A range of 50-200 g suspended loads was also used to express tipping (produced tipping moment) by offset suspension of a mass [11]. The interbracket distance (IBD) varied from 8 to $18 \mathrm{~mm}$ [16]. The simulation of the oral medium was achieved by using either human saliva [29], artificial saliva [30] or by applying different degrees of humidity $[6,31]$.

\section{DISCUSSION}

\subsection{Setup Evaluation Protocol}

As previously mentioned, the aim of this systematic review was to examine and compare the experimental designs used to quantify RS. Up to our knowledge, a similar work was never undertaken before. It is widely accepted that RS clinically affects treatment time in orthodontics [32]. Many variables have been described as influencing RS, such as material surface conditions [15] and material elasticity [27]. However, it is also acknowledged that RS is difficult to be evaluated in vivo. For this reason most of the studies follow in vitro models. There is a huge amount of very important information derived from those in vitro studies, including the possibility to design a more accurate, controlled method to evaluate RS. However, unfortunately, none of the validated tools for assessing risk of bias of the included studies can be used in this case. Even so, we find it worthwhile to analyze the existing information, and for that we designed a specific evaluation protocol that contains different studied clinical situations to assess the experimental designs as discussed later. Even with the obvious disadvantages, this is a standard procedure as performed in other studies [33].

The items selected in this evaluation protocol, based on the idea of full in vitro simulation of the in vivo conditions, represent different clinical situations that have been previously studied and reported in literature. All clinical scenarios reported in literature were included in this protocol except sliding velocity and occlusal forces (Table 3). Because of the complexity of achieving a speed comparable to the rate of orthodontic tooth movement (OTM) in vitro due to time limitations and mechanical considerations, the sliding velocity was not selected as a criterion in the established methodology assessment protocol. In vitro studies of orthodontic RS typically report values of either static (occurring instantaneously up to the initiation of sliding) or kinetic (occurring after the onset of sliding) frictional resistance as distinctly separated phases [34]. However, in vitro, this can be arbitrary and potentially misleading because at such low velocity, static and kinetic frictional resistances are dynamically related [34]. As the force required to initiate sliding by overcoming static friction is usually higher than kinetic friction [10], clinicians should be alert to the amount of force expected to be lost on overcoming static friction [35]. That is why laboratory tests were performed under relatively high velocities to distinguish between both. At the same time, occlusal forces were not included because their simulation is technically difficult, as they are not constant inter or intra individually, and they depend on other factors such as the facial or muscular pattern [36].

\subsection{Clinical Significance}

The established evaluation protocol contains all those parameters with evidence in literature of having a clinical influence in RS. It is not possible to decide what the most ideal way to evaluate RS is, but in our opinion, the more clinical scenarios replicated in a controlled way by a setup, the closer it would be to the real clinical conditions, and therefore better materials can be designed for most optimal use in those same clinical conditions. Our assessment does not aim to state that a particular setup is not adequate for the evaluation of the specific parameter for which it was designed, but to merely confirm that it is only evaluating that specific parameter. However, findings cannot be extrapolated to the clinical environment because both the experimental conditions and the in vivo conditions are not comparable. Although the specific setup may deliver reliable and accurate results, in the clinical environment these findings may be irrelevant or less prevalent because of the more complex in vivo interactions [32]. By including as many parameters as possible in a systematic and controllable way in one model, several variables could be evaluated either separately or synergistically, and because RS is a 
multifactorial event [37], a better understanding to this phenomenon could be achieved, which can certainly be of a great clinical benefit.

\subsection{The Evaluation Protocol}

The items used to compare the various experimental setups included the following studied clinical scenarios:

\subsubsection{Clinical simulation}

This was considered suitable when the design used a bracket/archwire interface to evaluate RS. Other interfaces such as flats, surfaces or disks were not considered as suitable alternatives because of differences in contact geometry between interfaces, and because they limit the investigation to the impact of materials only $[22,38]$. Moreover, using flats as counter-body instead of brackets would not be associated with archwire flexure against the bracket slot, which is involved in the resultant normal force as discussed later [12].

\subsubsection{Reciprocal sliding}

The majority of experimental setups used singlepass sliding (Appendix II). Reciprocal sliding is of great importance to simulate the actual OTM, because it is a discontinuous, dynamic motion instead of a continuous, linear one [6]. Also, using reciprocal, oscillating sliding instead of single-pass, linear sliding was reported to affect the results of RS evaluation differently [6].

\subsubsection{Displacements and angulations}

Clinically, a situation where there is no initial angulation or misalignment between bracket and archwire does not exist. Furthermore, binding and bracket/archwire angulation have an influence on RS [5]. So, it is very important to simulate at least some different tooth positions in a 3D space. Similarly, setting test brackets in arch-form is closer to the real clinical conditions than using single test brackets or aligning several brackets parallel to the wire, which was also reported to affect RS [39]. However, the assumed zero-angulation state was used in many designs to evaluate other variables except displacements, such as ligation technique [40] or archwire size $[30,41]$.

\subsubsection{Variability of the inter-bracket distance} (BBD)

The IBD varies depending upon the anatomical tooth position in the arch and the degree of malocclusion [29]. Therefore, it was found to be an important criterion that should exist in a setup for better clinical simulation.

\subsubsection{Oral atmosphere and temperature changes}

Designs suitable for performing tests under wet [42] or humid conditions [6] were considered to have an adequate environmental simulation, as sliding occurs actually under such conditions.

\subsubsection{Ligature and ligation force application}

Regarding ligation force application, the setups could be classified into three different categories: 1- Ligation force applied by the operators. This enables them to evaluate the influence of different ligature materials on RS [43-45], but it presents a risk of bias because of two factors: first, when metal ligatures are used, the ligation force may differ from one operator to another or even within the same operator. Second, when elastic ligatures are used, the force applied may decay over time [46]. 2- Studies where the ligation force was applied directly by the testing machine $[5,18,47]$. In such setups, a full control on the applied ligation force was achieved, although the influence of different ligature materials on RS could not be investigated. 3Studies combining both ligation systems, where a known weight was applied directly to the ligatures [48]. In this case, both the amount of ligation force and the effect of ligature material could be investigated.

\subsection{Relationship between Clinical Simula- tion and Evaluation of RS}

The experimental setups included in this review and their simulated clinical scenarios can be generally grouped into two main categories (Table 4):

\subsubsection{Archwire/bracket combination}

In this category test brackets were used as counter-bodies. This is more clinically relevant than other types of counter-bodies, and allows the investigation of the influence of bracket materials, design, and dimensions on RS. Based on sliding conditions, this category can be divided into two groups:

\subsubsection{Single-pass sliding}

This group can be further divided into two subdivisions based on angulation: 


\subsection{No angulation}

Archwires straight-line sliding through brackets parallel to brackets' slots. These setups, where second and third-order bracket angulations were kept at zero degrees, have been used to assess the influence of material, bracket design, bracket and wire dimensions, impact of saliva and different types of ligation [42,49,50]. The basic clinical scenario simulated was canine retraction or space closure with sliding mechanics $[42,49,50]$. However, the assumption that there is no angulation among the teeth is inaccurate, and OTM is not an entirely linear motion.

\subsection{Associated with $1^{\text {st }}, 2^{\text {nd }}$ and/or $3^{\text {rd }}$ order of angulation}

Archwires sliding through brackets with various static amounts of $1^{\text {st }}, 2^{\text {nd }}$ or $3^{\text {rd }}$ order of angulation (mostly evaluated separately). Studies of this group assess the contribution of bracket, archwire, and ligation types to RS while fixing orders of angulation at quantified increments, allowing the investigation of the influence of various amounts of angulation and displacement on RS [16,51-54]. Sliding mechanics during deflection, misalignment or malocclusion were the basic clinical concepts simulated in this group besides the tipping generated after the alignment phase. Archwire guided bodily OTM undergoes a force in the opposite direction of movement generated by tissue surrounding the root, leading to a tooth rotation around its center of resistance (tipping) [3]. Eventually, this will increase the load at the contact points between wire and bracket, and elastic deformity of archwire, producing antitip and anti-rotational movements of the teeth $[3,11]$. In some designs, approximated dental centers of resistance have been simulated to indirectly quantify second-order angulation effects of a stationary bracket relative to a linear archwire traction [11,55,56]. A quantified moment is generated to create a proportional secondorder angulation which is -in this case- not directly quantified but rather indirectly described in terms of the induced second-order moment. Again, an accurate simulation of OTM during the alignment phase is technically difficult because the displaced tooth does not remain in its position during alignment, and tooth movement is 3D in space. Due to this, tooth displacements and angulations are expressed apart in vitro. In the case of a static fixed amount of tipping, the anti-tip (uprighting) moment created in vivo by the elastic deformation at the bracket/archwire interface is overpowered, leading to a permanent deformation of the archwire and a greatly increased RS [57].

A subdivision of this group used a test bracket mounted with rotation freedom on a rotating disc. This subgroup differs in its passivity of secondorder angulation or tipping. The evaluation was performed under conditions of zero torque, but with passive self-centering tip [1,58], allowing the bracket to passively rotate through $360^{\circ}$ of $2^{\text {nd }}$ order angulation, and attempting to eliminate $2^{\text {nd }}$ order binding as a potential confounding variable [12].

Another subdivision of this group used a test bracket fixed on a tooth simulation or a dentoalveolar model. Biologic tooth movement was simulated through the application of a retarding force applied to the carriage-mounted housing, or through the viscosity of a polymer $[3,57]$. One of the most important features of this experimental design is the full 3D mobility of the simulated tooth although it was not fully controlled by force transducers in all planes of movement $[3,57]$. That makes it theoretically possible to simulate repeated tipping and uprighting cycles.

\subsubsection{Reciprocating sliding}

This group can be further grouped into two subdivisions based on angulation:

\subsection{No angulation}

Archwires straight-line sliding through brackets parallel to bracket slots $\left(2^{\text {nd }}\right.$ and $3^{\text {rd }}$ orders of angulation were kept at zero degrees) allow the investigation of the influence of bracket/archwire materials, design, and dimensions in addition to the impact of environmental medium and different amounts of ligation force, as well as the relationship between RS and wear, and the tribological behavior of materials $[6,47]$. Reciprocating motion with small repetitive displacements (back-and-forth movements) was used in this group. It approximates more to the real clinical scenario than linear single-pass regime because OTM is a dynamic and discontinuous motion with repetitive cycles of movement until the desired position is reached [59]. Reciprocating motion takes into consideration the resultant adhesive wear on interacting vibrating contacts which has an impact on RS [6]. 


\subsection{Tipping}

In this group, a rotational reciprocal motion was used (similar to pin-on-disk friction tester but with test bracket as a counter-body) allowing the investigation of RS and the degree of wear in addition to the impact of different bracket materials and design on RS [60]. This system can measure circular or reciprocating movements with various angular speeds. The used design allowed a gradual, continuous angular change in tipping [60].

\subsubsection{Archwire/flats or disks}

In this category, contact flats or disks were used as counter-bodies made of materials similar to brackets. Based on the sliding conditions, this category can be divided into two groups:

\subsubsection{Single-pass sliding}

Archwires straight-line sliding or traction through contact flats under variable amounts of ligation force and under different environmental settings $[22,38]$. It was assumed that an experimental setup must maintain a constant area of contact between sliding materials while ligation force is applied in order to measure the coefficient of friction [22]. However, the normal force on an archwire is clinically affected by either ligation force or wire flexure against the bracket slot [12], and such effects cannot be seen using contact flats, as wires do not show flexure under the pressure of the flats.

\subsubsection{Reciprocating sliding}

Pin-on-disk type friction tester, where the wire was pressed against a disk in a rotational reciprocating motion, allows the investigation of RS and the degree of wear between two materials [23,61]. Movements such as circular or reciprocating can be measured with various angular speeds.

So far, none of the setups published in literature permits a full, controlled 3D movement between bracket and archwire. The use of dental replicas can give an overall idea about the position of teeth in 3D space and its relation to RS, but a separate evaluation of each order of angulation can still not be achieved [29].

\subsection{Testing Conditions}

Different counter-bodies were used in setups, such as brackets [62], flats [38] or disks [61]
(Appendix II). The setup capability is affected by the type of counter-body used as previously mentioned. The ligation force was mostly achieved through ligatures, which is close to clinical situation. A ligation force average of 200 $\mathrm{g}$ was applied because it is comparable to the force applied by elastic ligatures [6]. It is very important to decide how to simulate the oral atmosphere in a setup. Human saliva or artificial saliva were mostly used as wet testing media. Human saliva has the advantage of being similar to clinical situations, although differences in viscosity among operators or degree of salivary stimulation may lead to different findings. However, non-significant differences on using human saliva of different viscosities were reported [63]. The period of exposure to saliva or wet medium may have an effect on the elastomeric ligature degradation in a way affecting RS [64]. No common trend of testing distance or testing time is noticed, however, many setups used a range of $8-18 \mathrm{~mm}$ sliding as it represents the distance of canine retraction into the extracted first premolar space $[1,3,30]$. Similarly, no common trend is applied to sliding velocities, which were relatively high as previously mentioned. The environmental temperature during testing, which was reported to influence RS [52], was usually room temperature under dry test conditions or around $37^{\circ} \mathrm{C}$ under wet test conditions to simulate body temperature.

\subsection{RS Evaluation in a Controlled Method and Its Technical Complexity: A Proposal}

Researchers have been aiming to provide improved, simple and repeatable designs in order to evaluate RS in a controlled manner. It is a fact that the current setups evaluate RS under one or two controlled parameters while others are isolated depending on the aim of the intended investigations. To fully understand RS and the in vivo interactions that take place, we should ideally think about evaluating RS involving interaction with more parameters. It is technically difficult to control many parameters at the same time, as well as it may increase the source of error. However, in our opinion, efforts should be directed toward achieving a clinical simulation as complete as possible by technical and practical improvement.

It could be concluded that single-pass motion together with a straight line traction are not the best way to simulate OTM. For in vivo simulation, 
Table 4. Classification of experimental designs and their limitations

\begin{tabular}{|c|c|c|c|}
\hline Combination type & Sliding direction & Angulation & Limitations \\
\hline \multirow[t]{3}{*}{ 1-Archwire/Bracket } & a- Single-pass & $\begin{array}{l}\text { i- No angulation } \\
\text { ii- } 1^{\text {st }}, 2^{\text {nd }} \text { or } 3^{\text {rd }} \\
\text { order }\end{array}$ & $\begin{array}{l}\text {-No angulations or displacements. } \\
\text {-Reciprocal sliding was not used. } \\
\text {-Static, fixed amounts of angulations } \\
\text { were mostly used instead of passive } \\
\text { ones. } \\
\text {-Displacement types could not be } \\
\text { evaluated together. } \\
\text {-Reciprocal sliding was not used. }\end{array}$ \\
\hline & b- Reciprocal & i- No angulation & $\begin{array}{l}\text {-No angulations or displacements. } \\
\text {-Only single test brackets were } \\
\text { used. }\end{array}$ \\
\hline & & ii- Tipping & $\begin{array}{l}\text {-Only single test brackets were } \\
\text { used. } \\
\text {-Other types of displacements could } \\
\text { not be evaluated. }\end{array}$ \\
\hline \multirow[t]{2}{*}{$\begin{array}{l}\text { 2-Archwire/Flats, } \\
\text { surfaces or disks }\end{array}$} & a- Single-pass & No angulation & $\begin{array}{l}\text {-Studies were limited to material } \\
\text { surfaces only. } \\
\text {-Different contact geometry. } \\
\text {-Reciprocal sliding was not used. }\end{array}$ \\
\hline & b- Reciprocal & No angulation & $\begin{array}{l}\text {-Studies were limited to material } \\
\text { surfaces only. } \\
\text {-Different contact geometry. }\end{array}$ \\
\hline
\end{tabular}

a design should be able to evaluate RS with integrated angular, linear and reciprocating movements as a function of time. The possibility of adding more axes of rotation to test brackets (or even wires) can be used to evaluate more orders of angulation to accurately assess RS in a $3 \mathrm{D}$ relationship, although it can be technically complicated. Setting multiple, movable test brackets on an arch will combine variable IBDs and curvatures of the arch on RS, and this, with different orders of angulation, will be a valuable tool to achieve different situations of malocclusion in vitro, linking that to RS. Also, combining ligation force application by a specified load with different ligature materials, will provide more reliable data regarding the influence of ligation on RS. Mounting test brackets to their corresponding archwires should be standardized, and be independent of bracket design. Additionally, an experimental device should be flexible to accommodate userspecificity. In order to reproduce oral atmosphere experimental settings, it would be desirable to obtain an environmental chamber that allows full control on temperature, humidity and medium of testing. However, the possibility to immerse test materials in a wet test solution could be advantageous to further investigate the influence of corrosion on RS.

\section{CONCLUSION}

Several in vitro designs were developed to isolate different variables influencing RS for specific purposes depending on the aims of the investigators. Generally, they used different techniques to quantify and to compare the mechanical efficiency of several bracket, archwire, and ligation combinations under different test conditions.

The so called "ideal experimental setup" or "the best way to evaluate RS" does not exist so far. However, the more clinical scenarios can be replicated by an experimental setup in a controlled way, the closer it would be to the clinical conditions. As RS is multifactorial, a design achieving various clinical scenarios and different setup combinations under full control would be desirable to investigate the influence of different related parameters in RS, either separately or synergistically, although it is indeed technically difficult.

Finally, operators should be aware of the testing conditions, and the fact that changes in these conditions will influence the outcome and degree of clinical simulation. 


\section{CONSENT}

It is not applicable.

\section{ETHICAL APPROVAL}

It is not applicable.

\section{COMPETING INTERESTS}

Authors have declared that no competing interests exist.

\section{REFERENCES}

1. Kapila S, Angolkar PV, Duncanson MG Jr, Nanda RS. Evaluation of friction between edgewise stainless steel brackets and orthodontic wires of four alloys. Am J Orthod Dentofacial Orthop. 1990;98(2): 117-26.

[10.1016/0889-5406(90)70005-w]

2. Nicolls J. Frictional forces in fixed orthodontic appliances. Dent Pract Dent Rec. 1968;18(10):362-6.

3. Drescher D, Bourauel C, Schumacher HA. Frictional forces between bracket and arch wire. Am J Orthod Dentofacial Orthop. 1989;96(5):397-404.

4. Ogata $\mathrm{RH}$, Nanda RS, Duncanson MG Jr, Sinha PK, Currier GF. Frictional resistances in stainless steel bracket-wire combinations with effects of vertical deflections. Am J Orthod Dentofacial Orthop. 1996;109(5):535-42.

5. Zufall SW, Kennedy KC, Kusy RP. Frictional characteristics of composite orthodontic archwires against stainless steel and ceramic brackets in the passive and active configurations. J Mater Sci Mater Med. 1998;9(11):611-20.

6. Willems G, Clocheret K, Celis JP, Verbeke G, Chatzicharalampous E, Carels C. Frictional behavior of stainless steel bracket-wire combinations subjected to small oscillating displacements. Am J Orthod Dentofacial Orthop. 2001;120(4): $371-7$

[10.1067/mod.2001.116088]

7. Baccetti T, Franchi L. Friction produced by types of elastomeric ligatures in treatment mechanics with the preadjusted appliance. Angle Orthod. 2006;76(2):211-6.

[10.1043/0003-

3219(2006)076[0211:fpbtoe]2.0.co;2]
8. Kim TK, Kim KD, Baek SH. Comparison of frictional forces during the initial leveling stage in various combinations of selfligating brackets and archwires with a custom-designed typodont system. Am J Orthod Dentofacial Orthop. 2008;133(2): 187.e15-24.

[10.1016/j.ajodo.2007.08.013]

9. Bhushan B. Introduction to Tribology. 2nd ed. New York: John Wiley \& Sons, Ltd.; 2013.

10. Burrow SJ. Friction and resistance to sliding in orthodontics: a critical review. Am J Orthod Dentofacial Orthop. 2009;135(4):442-7.

[10.1016/j.ajodo.2008.09.023]

11. Tidy DC. Frictional forces in fixed appliances. Am J Orthod Dentofacial Orthop. 1989;96(3):249-54.

12. Kamelchuk LS, Rossouw PE. Development of a laboratory model to test kinetic orthodontic friction. Semin Orthod. 2003;9(4):251-61.

13. Moher D, Liberati A, Tetzlaff J, Altman DG, The Prisma Group. Preferred reporting items for systematic reviews and metaanalyses: The PRISMA statement. Ann Intern Med. 2009;151(4):264-9.

[10.7326/0003-4819-151-4-20090818000135]

14. Oka K, Endo $\mathrm{T}$, Wada $\mathrm{H}$, Minegishi $\mathrm{T}$, Akashiba T, Amano N, et al. Study on frictional characteristics of $\mathrm{KB}$ horizontal brackets. A comparative study of kinetic frictional forces to be caused between various kinds of brackets and wires. Shigaku. 1989;77(4):1458-69.

15. Kusy RP, Whitley JQ. Coefficients of friction for arch wires in stainless steel and polycrystalline alumina bracket slots. I. The dry state. Am J Orthod Dentofacial Orthop. 1990;98(4):300-12. [10.1016/s0889-5406(05)81487-8]

16. Kusy RP, Whitley JQ. Resistance to sliding of orthodontic appliances in the dry and wet states: Influence of archwire alloy, interbracket distance, and bracket engagement. J Biomed Mater Res. 2000;52(4):797-811.

17. Stefanos S, Secchi AG, Coby G, Tanna N, Mante FK. Friction between various selfligating brackets and archwire couples during sliding mechanics. Am J Orthod Dentofacial Orthop. 2010;138(4):463-7. [10.1016/j.ajodo.2008.11.029]

18. Michelberger DJ, Eadie RL, Faulkner MG, Glover KE, Prasad NG, Major PW. The 
friction and wear patterns of orthodontic brackets and archwires in the dry state. Am J Orthod Dentofacial Orthop. 2000;118(6):662-74.

[10.1067/mod.2000.105529]

19. Arun AV, Vaz AC. Frictional characteristics of the newer orthodontic elastomeric ligatures. Indian J Dent Res. 2011;22(1): 95-9.

[10.4103/0970-9290.80005]

20. Muguruma $\mathrm{T}$, lijima $\mathrm{M}$, Brantley WA, Mizoguchi I. Effects of a diamond-like carbon coating on the frictional properties of orthodontic wires. Angle Orthod. 2011;81(1):141-48.

[10.2319/052110-276.1]

21. Regis $S$ Jr, Soares $P$, Camargo ES, Guariza Filho O, Tanaka O, Maruo H. Biodegradation of orthodontic metallic brackets and associated implications for friction. Am J Orthod Dentofacial Orthop. 2011;140(4):501-9.

[10.1016/j.ajodo.2011.01.023]

22. Stannard JG, Gau JM, Hanna MA. Comparative friction of orthodontic wires under dry and wet conditions. Am J Orthod. 1986;89(6):485-91.

23. Alfonso MV, Espinar E, Llamas JM, Ruperez E, Manero JM, Barrera JM, et al. Friction coefficients and wear rates of different orthodontic archwires in artificial saliva. J Mater Sci Mater Med. 2013;24(5):1327-32.

[10.1007/s10856-013-4887-4]

24. Hosseinzadeh Nik $T$, Hooshmand $T$, Farazdaghi H, Mehrabi A, Razavi ES. Effect of chlorhexidine-containing prophylactic agent on the surface characterization and frictional resistance between orthodontic brackets and archwires: An in vitro study. Prog Orthod. 2013;14:48.

[10.1186/2196-1042-14-48]

25. Sukh R, Singh GK, Tandon P, Singh GP, Singh A. A comparative study of frictional resistance during simulated canine retraction on typodont model. J Orthod Sci. 2013;2(2):61-6.

[10.4103/2278-0203.115091]

26. Suryawanshi GR, Sundareswaran S, Philip $\mathrm{K}$, Kumar S. In vitro evaluation of different methods of ligation on friction in sliding mechanics. Orthodontics (Chic.). 2013;14(1):e102-9.

[10.11607/ortho.905]

27. Liaw YC, Su YY, Lai YL, Lee SY. Stiffness and frictional resistance of a superelastic nickel-titanium orthodontic wire with lowstress hysteresis. Am J Orthod Dentofacial Orthop. 2007;131(5):578.e12-8. [10.1016/j.ajodo.2006.08.015]

28. Crincoli V, Perillo L, Di Bisceglie MB, Balsamo A, Serpico V, Chiatante F, et al. Friction forces during sliding of various brackets for malaligned teeth: An in vitro study. Scientific World Journal. 2013;2013: 871423.

[10.1155/2013/871423]

29. Henao SP, Kusy RP. Evaluation of the frictional resistance of conventional and self-ligating bracket designs using standardized archwires and dental typodonts. Angle Orthod. 2004;74(2):20211. [10.1043/00033219(2004)074<0202:eotfro>2.0.co;2]

30. Garner LD, Allai WW, Moore BK. A comparison of frictional forces during simulated canine retraction of a continuous edgewise arch wire. Am J Orthod Dentofacial Orthop. 1986;90(3):199-203.

31. Kuroe K, Tajiri T, Nakayama T, Nagakubo C, Kubota S, Matsuda T, et al. Frictional forces with the friction-free edgewise bracket. J Clin Orthod. 1994;28(6):347-51.

32. Rossouw PE. Friction: An overview. Seminars in Orthodontics. 2003;9(4):21822.

Available:http://dx.doi.org/10.1016/j.sodo.2 003.08.002

33. Ehsani S, Mandich MA, El-Bialy $\mathrm{TH}$, Flores-Mir C. Frictional resistance in selfligating orthodontic brackets and conventionally ligated brackets. A systematic review. Angle Orthod. 2009;79(3):592-601.

[10.2319/060208-288.1]

34. Rossouw PE, Kamelchuk LS, Kusy RP. A fundamental review of variables associated with low velocity frictional dynamics. Semin Orthod. 2003;9(4):223-35.

35. Frank CA, Nikolai RJ. A comparative study of frictional resistances between orthodontic bracket and arch wire. Am J Orthod. 1980;78(6):593-609.

36. Custodio W, Gomes SGF, Faot F, Garcia RCMR, Del Bel Cury AA. Occlusal force, electromyographic activity of masticatory muscles and mandibular flexure of subjects with different facial types. J Appl Oral Sci. 2011;19(4):343-9.

[10.1590/S1678-77572011005000008]

37. Tageldin $\mathrm{H}$, Cadenas de Llano-Pérula $\mathrm{M}$, Thevissen $\mathrm{P}$, Celis JP, Willems $\mathrm{G}$. 
Resistance to sliding in orthodontics: a systematic review. J J Dent Res. 2016;3(1):034.

38. Kusy RP, Whitley JQ. Effects of sliding velocity on the coefficients of friction in a model orthodontic system. Dent Mater. 1989;5(4):235-40.

39. Fourie Z, Ozcan M, Sandham A. Effect of dental arch convexity and type of archwire on frictional forces. Am $\mathrm{J}$ Orthod Dentofacial Orthop. 2009;136(1):14.e1-7; discussion -5 .

[10.1016/j.ajodo.2008.06.026]

40. Leal RC, Amaral FL, Franca FM, Basting RT, Turssi CP. Role of lubricants on friction between self-ligating brackets and archwires. Angle Orthod. 2014;84(6):104953.

[10.2319/110513-805.1]

41. Taylor NG, Ison K. Frictional resistance between orthodontic brackets and archwires in the buccal segments. Angle Orthod. 1996;66(3):215-22.

[10.1043/0003-

3219(1996)066<0215:frboba>2.3.co;2]

42. Baker KL, Nieberg LG, Weimer AD, Hanna $M$. Frictional changes in force values caused by saliva substitution. Am J Orthod Dentofacial Orthop. 1987;91(4):316-20.

43. Mendes K, Rossouw PE. Friction: Validation of manufacturer's claim. Semin Orthod. 2003;9:236-50.

44. Griffiths HS, Sherriff M, Ireland AJ. Resistance to sliding with 3 types of elastomeric modules. Am J Orthod Dentofacial Orthop. 2005;127(6):670-5; quiz 754.

[10.1016/j.ajodo.2004.01.025]

45. Kumar S, Singh S, Hamsa PRR, Ahmed S, Prasanthma, Bhatnagar A, et al. Evaluation of friction in orthodontics using various brackets and archwire combinations-an in vitro study. J Clin Diagn Res. 2014;8(5):Zc33-6. [10.7860/jcdr/2014/7990.4364]

46. Keith O, Jones SP, Davies EH. The influence of bracket material, ligation force and wear on frictional resistance of orthodontic brackets. $\mathrm{Br} J$ Orthod. 1993;20(2):109-15.

47. Al-Khatib S, Berradja A, Celis JP, Willems G. In vitro friction of stainless steel arch wire-bracket combinations in air and different aqueous solutions. Orthod Craniofac Res. 2005;8(2):96-105. [10.1111/j.1601-6343.2005.00321.x]
48. Edwards GD, Davies EH, Jones SP. The ex vivo effect of ligation technique on the static frictional resistance of stainless steel brackets and archwires. $\mathrm{Br} \mathrm{J}$ Orthod. 1995;22(2):145-53.

49. Hain M, Dhopatkar A, Rock P. The effect of ligation method on friction in sliding mechanics. Am J Orthod Dentofacial Orthop. 2003;123(4):416-22.

[10.1067/mod.2003.14]

50. Tecco S, Festa F, Caputi S, Traini T, Di Iorio D, D'Attilio M. Friction of conventional and self-ligating brackets using a 10 bracket model. Angle Orthod. 2005;75(6): 1041-5.

[10.1043/00033219(2005)75[1041:focasb]2.0.co;2]

51. Murayama M, Namura $\mathrm{Y}$, Tamura $\mathrm{T}$, Iwai $\mathrm{H}$, Shimizu N. Relationship between friction force and orthodontic force at the leveling stage using a coated wire. J Appl Oral Sci. 2013;21(6):554-9. [10.1590/1679-775720130325]

52. Chang CJ, Lee TM, Liu JK. Effect of bracket bevel design and oral environmental factors on frictional resistance. Angle Orthod. 2013;83(6):956-65.

[10.2319/101612-808.1]

53. Chung M, Nikolai RJ, Kim KB, Oliver DR. Third-order torque and self-ligating orthodontic bracket-type effects on sliding friction. Angle Orthod. 2009;79(3):551-7.

[10.2319/022608-114.1]

54. Redlich M, Mayer Y, Harari D, Lewinstein I. In vitro study of frictional forces during sliding mechanics of "reduced-friction" brackets. Am J Orthod Dentofacial Orthop. 2003;124(1):69-73.

[10.1016/s0889540603002385]

55. Bednar JR, Gruendeman GW, Sandrik JL. A comparative study of frictional forces between orthodontic brackets and arch wires. Am J Orthod Dentofacial Orthop. 1991;100(6):513-22.

[10.1016/0889-5406(91)70091-a]

56. Pliska BT, Beyer JP, Larson BE. A comparison of resistance to sliding of selfligating brackets under an increasing applied moment. Angle Orthod. 2011;81(5):794-9. [10.2319/111510-666.1]

57. Budd S, Daskalogiannakis J, Tompson BD. A study of the frictional characteristics of four commercially available self-ligating bracket systems. Eur J Orthod. 2008;30(6):645-53.

[10.1093/ejo/cjn058] 
58. Bazakidou E, Nanda RS, Duncanson MG Jr, Sinha P. Evaluation of frictional resistance in esthetic brackets. Am J Orthod Dentofacial Orthop. 1997;112(2): 138-44.

59. Nikolai RJ. Bioengineering analysis of orthodontic mechanics. Philadelphia: Lea \& Febiger; 1985.

60. Park JH, Lee YK, Lim BS, Kim CW. Frictional forces between lingual brackets and archwires measured by a friction tester. Angle Orthod. 2004;74(6):816-24. [10.1043/00033219(2004)074<0816:ffblba>2.0.co;2]

61. Gil FJ, Solano E, Campos A, Boccio F, Saez I, Alfonso MV, et al. Improvement of the friction behaviour of $\mathrm{NiTi}$ orthodontic archwires by nitrogen diffusion. Biomed Mater Eng. 1998;8(5-6):335-42.

62. Sadique S, Ramakrishna S. In vitro frictional behavior and wear patterns between contemporary and aesthetic composite orthodontic brackets and archwires. Wear. 2006;261(10):1121-39. [10.1016/j.wear.2006.03.035]

63. Kusy RP, Schafer DL. Effect of salivary viscosity on frictional coefficients of orthodontic archwire/bracket couples. J Mater Sci Mater Med. 1995;6:390-5.

64. Edwards IR, Spary DJ, Rock WP. The effect upon friction of the degradation of orthodontic elastomeric modules. Eur $\mathrm{J}$ Orthod. 2012;34(5):618-24.

[10.1093/ejo/cjr052]

65. Lee SH, Chang YI. Effects of recycling on the mechanical properties and the surface topography of nickel-titanium alloy wires. Am J Orthod Dentofacial Orthop. 2001;120(6):654-63.

[10.1067/mod.2001.118997]

66. Liew CF, Brockhurst P, Freer TJ. Frictional resistance to sliding archwires with repeated displacement. Aust Orthod J. 2002;18(2):71-5.

67. Sirisaowaluk N, Kravchuk O, Ho CT. The influence of ligation on frictional resistance to sliding during repeated displacement. Aust Orthod J. 2006;22(2):141-6.

68. Hsu J, Wu L. Frictional forces of conventional and improved superelastic NiTi-alloy orthodontic archwires in stainless steel and plastic brackets. IFMBE Proceedings. 2009;25:312-5.

69. Alavi S, Farahi A. Effect of fluoride on friction between bracket and wire. Dent Res J. 2011;8(Suppl 1):S37-42.
70. Choi SH, Kang DY, Hwang CJ. Surface roughness of three types of modern plastic bracket slot floors and frictional resistance. Angle Orthod. 2014;84(1):177-83.

[10.2319/030313-179.1]

71. Gandini P, Orsi L, Bertoncini C, Massironi $\mathrm{S}$, Franchi L. In vitro frictional forces generated by three different ligation methods. Angle Orthod. 2008;78(5):917-21.

[10.2319/090607-420.1]

72. Chimenti C, Franchi L, Di Giuseppe MG, Lucci M. Friction of orthodontic elastomeric ligatures with different dimensions. Angle Orthod. 2005;75(3):421-5.

[10.1043/00033219(2005)75[421:fooelw]2.0.co;2]

73. Rozzi M, Mucedero M, Franchi L, Cozza P. Friction in a hybrid system. An in vitro study. Oral Implantology. 2010;3(4):2-8.

74. Liu X, Lin J, Ding P. Changes in the surface roughness and friction coefficient of orthodontic bracket slots before and after treatment. Scanning. 2013;35(4):26572. [10.1002/sca.21060]

75. Kapur Wadhwa R, Kwon HK, Close JM. Frictional resistances of different bracketwire combinations. Aust Orthod J. 2004;20(1):25-30.

76. Voudouris JC, Schismenos C, Lackovic K, Kuftinec MM. Self-ligation esthetic brackets with low frictional resistance. Angle Orthod. 2010;80(1):188-94.

[10.2319/110608-565.1]

77. Pacheco MR, Oliveira DD. Evaluation of friction in self-ligating brackets subjected to sliding mechanics: An in vitro study. Dental Press J Orthod. 2011;16(1):107-15.

78. Mendes Bde A, Neto Ferreira RA, Pithon MM, Horta MC, Oliveira DD. Physical and chemical properties of orthodontic brackets after 12 and 24 months: in situ study. J Appl Oral Sci. 2014;22(3):194-203.

79. Kahlon S, Rinchuse D, Robison JM, Close JM. In-vitro evaluation of frictional resistance with 5 ligation methods and Gianelly-type working wires. Am J Orthod Dentofacial Orthop. 2010;138(1):67-71. [10.1016/j.ajodo.2008.07.023]

80. Nair SV, Padmanabhan R, Janardhanam $P$. Evaluation of the effect of bracket and archwire composition on frictional forces in the buccal segments. Indian J Dent Res. 2012;23(2):203-8. [10.4103/0970-9290.100426]

81. Pillai AR, Gangadharan A, Kumar S, Shah A. Comparison of the frictional resistance between archwire and different bracket 
system: An in vitro study. J Pharm Bioallied Sci. 2014;6(Suppl 1):S150-5.

[10.4103/0975-7406.137429]

82. Rongo $R$, Ametrano G, Gloria A, Spagnuolo G, Galeotti A, Paduano S, et al. Effects of intraoral aging on surface properties of coated nickel-titanium archwires. Angle Orthod. 2014;84(4):665-72. [10.2319/081213-593.1]

83. Aloysius AP, Vijayalakshmi D, Deepika, Soundararajan NK, Manohar VN, Khan N. Comparative evaluation of frictional properties, load deflection rate and surface characteristics of different coloured TMA archwires - An in vitro study. J Clin Diagn Res. 2015;9(12):Zc26-9.

[10.7860/jcdr/2015/16117.6962]

84. Juvvadi SR, Kailasam V, Padmanabhan S, Chitharanjan AB. Physical, mechanical, and flexural properties of 3 orthodontic wires: an in-vitro study. Am J Orthod Dentofacial Orthop. 2010;138(5):623-30. [10.1016/j.ajodo.2009.01.032]

85. Oh KT, Choo SU, Kim KM, Kim KN. A stainless steel bracket for orthodontic application. Eur J Orthod. 2005;27(3):23744.

[10.1093/ejo/cji005]

86. Thermac G, Morgon L, Godeneche J. [Friction: Self-ligating brackets]. Orthod Fr. 2008;79(4):239-49.

[10.1051/orthodfr:2008016]

87. Zhu K, Wang CL, Wang J, Zhao YH. Comparison study of friction of FAS selfligating bracket and traditional self-ligating bracket. Hua Xi Kou Qiang Yi Xue Za Zhi. 2007;25(4):371-4.

88. Lombardo L, Wierusz W, Toscano D, Lapenta R, Kaplan A, Siciliani G. Frictional resistance exerted by different lingual and labial brackets: An in vitro study. Prog Orthod. 2013;14:37.

[10.1186/2196-1042-14-37]

89. Lin HP, Wu JY. A study of frictional resistance of archwires and ligating methods. Shanghai Kou Qiang Yi Xue. 2005;14(2):164-8.

90. Xiaowei L, Luyi Y, Huifang Z, Yan D, Qi W, Wei J, et al. Comparison of friction force between Lock-loose bracket and traditional bracket. Hua Xi Kou Qiang Yi Xue Za Zhi. 2014;32(6):570-4.

91. Voudouris JC. Interactive edgewise mechanisms: Form and function comparison with conventional edgewise brackets. Am J Orthod Dentofacial Orthop. 1997;111(2):119-40.
92. Fernandes DJ, Miguel JA, Quintao CC, Elias CN. Evaluation of frictional forces of polycarbonate self-ligating brackets. World J Orthod. 2010;11(3):250-5.

93. Parmagnani EA, Basting RT. Effect of sodium bicarbonate air abrasive polishing on attrition and surface micromorphology of ceramic and stainless steel brackets. Angle Orthod. 2012;82(2):351-62.

[10.2319/040111-235.1]

94. Berger JL. The influence of the SPEED bracket's self-ligating design on force levels in tooth movement: a comparative in vitro study. Am J Orthod Dentofacial Orthop. 1990;97(3):219-28.

[10.1016/s0889-5406(05)80055-1]

95. Shivapuja PK, Berger J. A comparative study of conventional ligation and selfligation bracket systems. Am J Orthod Dentofacial Orthop. 1994;106(5):472-80. [10.1016/s0889-5406(94)70069-9]

96. Braun S, Bluestein M, Moore BK, Benson G. Friction in perspective. Am $\mathrm{J}$ Orthod Dentofacial Orthop. 1999;115(6):619-27.

97. Kao CT, Ding SJ, Wang CK, He H, Chou MY, Huang TH. Comparison of frictional resistance after immersion of metal brackets and orthodontic wires in a fluoride-containing prophylactic agent. Am J Orthod Dentofacial Orthop. 2006;130(5):568.e1-9.

[10.1016/j.ajodo.2005.09.028]

98. Crawford NL, McCarthy C, Murphy TC, Benson PE. Physical properties of conventional and super slick elastomeric ligatures after intraoral use. Angle Orthod. 2010;80(1):175-81. [10.2319/013009-63.1]

99. Vinay K, Venkatesh MJ, Nayak RS, Pasha A, Rajesh M, Kumar P. A comparative study to evaluate the effects of ligation methods on friction in sliding mechanics using 0.022" slot brackets in dry state: An In-vitro study. J Int Oral Health. 2014;6(2):76-83.

100. Williams CL, Khalaf K. Frictional resistance of three types of ceramic brackets. J Oral Maxillofac Res. 2013;4(4):e3.

[10.5037/jomr.2013.4403]

101. Khambay B, Millett D, McHugh S. Evaluation of methods of archwire ligation on frictional resistance. Eur $\mathrm{J}$ Orthod. 2004;26(3):327-32.

102. Pratten DH, Popli K, Germane N, Gunsolley JC. Frictional resistance of ceramic and stainless steel orthodontic 
brackets. Am J Orthod Dentofacial Orthop. 1990;98(5):398-403.

[10.1016/s0889-5406(05)81647-6]

103. Suwa N, Watari F, Yamagata S, lida J, Kobayashi M. Static-dynamic friction transition of FRP esthetic orthodontic wires on various brackets by suspension-type friction test. J Biomed Mater Res B Appl Biomater. 2003;67(2):765-71.

[10.1002/jbm.b.10032]

104. Tai YY, Hsu SH, Chen RS, Su WF, Chen $\mathrm{MH}$. Liquid crystalline epoxy nanocomposite material for dental application. J Formos Med Assoc. 2015;114(1):46-51.

[10.1016/j.jfma.2014.01.018]

105. Kannan MS, Murali RV, Kishorekumar S, Gnanashanmugam K, Jayanth V. Comparison of frictional resistance of esthetic and semi-esthetic self-ligating brackets. J Pharm Bioallied Sci. 2015;7(Suppl 1):S116-20. [10.4103/0975-7406.155852]

106. Kaur G, Goyal S, Rajpal S, Gera A. Comparative evaluation of frictional forces of conventional and self-ligating bracket systems: An in vitro study. J Ind Orthod Soc. 2013;47(4):211-6.

107. Ben Rejeb Jdir S, Tobji S, Turki W, Dallel I, Khedher N, Ben Amor A. Brackets and friction in orthodontics: Experimental study. Orthod Fr. 2015;86(3):255-64.

[10.1051/orthodfr/2015026]

108. Wichelhaus A, Geserick M, Hibst R, Sander FG. The effect of surface treatment and clinical use on friction in $\mathrm{NiTi}$ orthodontic wires. Dent Mater. $2005 ; 21(10): 938-45$.

[10.1016/j.dental.2004.11.011]

109. Espinar E, Llamas JM, Michiardi A, Ginebra MP, Gil FJ. Reduction of $\mathrm{Ni}$ release and improvement of the friction behaviour of NiTi orthodontic archwires by oxidation treatments. J Mater Sci Mater Med. 2011;22(5):1119-25.

[10.1007/s10856-011-4292-9]

110. Leite VV, Lopes MB, Gonini Junior A, Almeida MR, Moura SK, Almeida RR. Comparison of frictional resistance between self-ligating and conventional brackets tied with elastomeric and metal ligature in orthodontic archwires. Dental Press J Orthod. 2014;19(3):114-9.

111. de Lima Mendonca S, Praxedes Neto OJ, de Oliveira PT, dos Santos PB, de Sa Leitao Pinheiro $\mathrm{FH}$. Comparison of friction produced by two types of orthodontic bracket protectors. Dental Press J Orthod. 2014;19(1):86-91.

112. Bandeira AM, dos Santos MP, Pulitini G, Elias CN, da Costa MF. Influence of thermal or chemical degradation on the frictional force of an experimental coated NiTi wire. Angle Orthod. 2011;81(3):484-9. [10.2319/042810-232.1]

113. Cunha AC, Marquezan M, Freitas AO, Nojima LI. Frictional resistance of orthodontic wires tied with 3 types of elastomeric ligatures. Braz Oral Res. $2011 ; 25(6): 526-30$.

114. Fidalgo TK, Pithon MM, Maciel JV, Bolognese AM. Friction between different wire bracket combinations in artificial saliva-- an in vitro evaluation. J Appl Oral Sci. 2011;19(1):57-62.

115. Brauchli LM, Senn C, Wichelhaus A. Active and passive self-ligation-a myth? Angle Orthod. 2011;81(2):312-8.

[10.2319/041310-205.1]

116. Cacciafesta V, Sfondrini MF, Ricciardi A, Scribante A, Klersy C, Auricchio F. Evaluation of friction of stainless steel and esthetic self-ligating brackets in various bracket-archwire combinations. Am J Orthod Dentofacial Orthop. 2003;124(4): 395-402. [10.1016/s0889540603005043]

117. Galvao MB, Camporesi M, Tortamano A, Dominguez GC, Defraia E. Frictional resistance in monocrystalline ceramic brackets with conventional and nonconventional elastomeric ligatures. Prog Orthod. 2013;14:9.

[10.1186/2196-1042-14-9]

118. De Franco DJ, Spiller RE Jr. Frictional resistances using Teflon-coated ligatures with various bracket-archwire combinations. Angle Orthod. 1995;65(1):63-74.

[10.1043/00033219(1995)065<0063:frutlw>2.0.co;2]

119. Dowling PA, Jones WB, Lagerstrom $L$, Sandham JA. An investigation into the behavioural characteristics of orthodontic elastomeric modules. $\mathrm{Br} J$ Orthod. 1998;25(3):197-202.

120. Oliver CL, Daskalogiannakis J, Tompson BD. Archwire depth is a significant parameter in the frictional resistance of active and interactive, but not passive, selfligating brackets. Angle Orthod. 2011;81(6):1036-44. [10.2319/122810-751.1]

121. Chng CK, Foong K, Gandedkar NH, Chan $\mathrm{YH}$, Chew CL. A new esthetic fiber- 
reinforced polymer composite resin archwire: A comparative atomic force microscope (AFM) and field-emission scanning electron microscope (FESEM) study. Prog Orthod. 2014;15(1):39.

[10.1186/s40510-014-0039-8]

122. Wong JK, Romanyk DL, Toogood RW, Heo G, Carey JP, Major PW. The effect of perturbations on resistance to sliding in second-order moments comparing two different bracket types. J Dent Biomech. 2014;5:1758736014557500.

[10.1177/1758736014557500]

123. Castro RM, Neto PS, Horta MC, Pithon MM, Oliveira DD. Comparison of static friction with self-ligating, modified slot design and conventional brackets. J Appl Oral Sci. 2013;21(4):314-9.

[10.1590/1678-775720130097]

124. Samorodnitzky-Naveh G, Redlich M. Inorganic fullerene-like tungsten disulfide nanocoating for friction reduction of nickel-titanium alloys. Nanomedicine. 2009;4(8):943-50.

125. Ioi $H$, Yanase $Y$, Uehara $M$, Hara $A$, Nakata S, Nakasima A, et al. Frictional resistance in plastic preadjusted brackets ligated with low-friction and conventional elastomeric ligatures. J Orthod. 2009; 36(1):17-22; discussion 13.

[10.1179/14653120722887]

126. Yanase $Y$, loi $H$, Nishioka M, Takahashi I. Effects of sliding velocity on friction: An in vitro study at extremely low sliding velocity approximating orthodontic tooth movement. Angle Orthod. 2014;84(3):451-8. [10.2319/060513-427.1]

127. Olson JE, Liu Y, Nickel JC, Walker MP, Iwasaki LR. Archwire vibration and stickslip behavior at the bracket-archwire interface. Am J Orthod Dentofacial Orthop. 2012;142(3):314-22. [10.1016/j.ajodo.2012.03.032]

128. Jordan L, Garrec P, Prima F. Influence of shape memory properties on sliding resistance in fixed orthodontic appliances. Mater Sci Forum. 2012;706-709:514-9. [10.4028/www.scientific.net/MSF.706709.514]

129. Monteiro MR, Silva LE, Elias CN, Vilella Ode V. Frictional resistance of self-ligating versus conventional brackets in different bracket-archwire-angle combinations. J Appl Oral Sci. 2014;22(3):228-34.

130. Omana HM, Moore RN, Bagby MD. Frictional properties of metal and ceramic brackets. J Clin Orthod. 1992;26(7):42532.

131. Iwasaki LR, Beatty MW, Randall CJ, Nickel JC. Clinical ligation forces and intraoral friction during sliding on a stainless steel archwire. Am J Orthod Dentofacial Orthop. 2003;123(4):408-15. [10.1067/mod.2003.61]

132. O'Reilly D, Dowling PA, Lagerstrom L, Swartz ML. An ex-vivo investigation into the effect of bracket displacement on the resistance to sliding. $\mathrm{Br} J$ Orthod. 1999;26(3):219-27.

133. Ozturk Ortan Y, Yurdakuloglu Arslan T, Aydemir B. A comparative in vitro study of frictional resistance between lingual brackets and stainless steel archwires. Eur J Orthod. 2012;34(1):119-25.

[10.1093/ejo/cja180]

134. Schumacher HA, Bourauel C, Drescher D. Frictional forces when rectangular guiding arches with varying edge bevel are employed. J Orofac Orthop. 1998;59(3): 139-49.

135. Tanne K, Matsubara S, Hotei Y, Sakuda $M$, Yoshida M. Frictional forces and surface topography of a new ceramic bracket. Am J Orthod Dentofacial Orthop. 1994;106(3):273-8.

[10.1016/s0889-5406(94)70047-8]

136. Wilmes B, Vali S, Drescher D. In-vitro study of surface changes in fixed orthodontic appliances following air polishing with clinpro prophy and air-flow. J Orofac Orthop. 2009;70(5):371-84. [10.1007/s00056-009-9907-0]

137. Yamaguchi K, Nanda RS, Morimoto N, Oda Y. A study of force application, amount of retarding force, and bracket width in sliding mechanics. Am $\mathrm{J}$ Orthod Dentofacial Orthop. 1996;109(1):50-6.

138. Liu X, Ding P, Lin J. Effects of bracket design on critical contact angle. Angle Orthod. 2013;83(5):877-84. [10.2319/080112-621.1]

139. Ding $\mathrm{P}$, Lin JX, Zhou YH. Development and preliminary application of orthodontic friction dynamic testing apparatus. Beijing Da Xue Xue Bao. 2009;41(3):319-23.

140. Pattan SK, Peddu R, Bandaru SK, Lanka D, Mallavarapu K, Pathan AB. Efficacy of super slick elastomeric modules in reducing friction during sliding: $A$ comparative in vitro study. J Contemp Dent Pract. 2014;15(5):543-51.

141. Reicheneder CA, Baumert U, Gedrange T, Proff P, Faltermeier A, Muessig D. 
Frictional properties of aesthetic brackets. Eur J Orthod. 2007;29(4):359-65.

[10.1093/ejo/cjm033]

142. Prososki RR, Bagby MD, Erickson LC. Static frictional force and surface roughness of nickel-titanium arch wires. Am J Orthod Dentofacial Orthop. 1991;100(4):341-8. [10.1016/0889-5406(91)70072-5]

143. Downing A, McCabe JF, Gordon PH. The effect of artificial saliva on the frictional forces between orthodontic brackets and archwires. Br J Orthod. 1995;22(1):41-6.

144. Downing A, McCabe J, Gordon P. A study of frictional forces between orthodontic brackets and archwires. $\mathrm{Br} \mathrm{J}$ Orthod. 1994;21(4):349-57.

145. Jakob SR, Matheus D, Jimenez-Pellegrin MC, Turssi CP, Amaral FL. Comparative study of friction between metallic and conventional interactive self-ligating brackets in different alignment conditions. Dental Press J Orthod. 2014;19(3):82-9.

146. Hamdan A, Rock $P$. The effect of different combinations of tip and torque on archwire/bracket friction. Eur J Orthod. 2008;30(5):508-14.

[10.1093/ejo/cjn017]

147. Moore MM, Harrington E, Rock WP. Factors affecting friction in the preadjusted appliance. Eur $\mathrm{J}$ Orthod. 2004;26(6):579-83.

[10.1093/ejo/26.6.579]

148. Marques IS, Araujo AM, Gurgel JA, Normando D. Debris, roughness and friction of stainless steel archwires following clinical use. Angle Orthod. 2010;80(3):521-7.

[10.2319/081109-457.1]

149. Dos Santos AA, Pithon MM, Carlo FG, Carlo HL, de Lima BA, Dos Passos TA, et al. Effect of time and $\mathrm{pH}$ on physicalchemical properties of orthodontic brackets and wires. Angle Orthod; 2014.

[10.2319/032914-234.1]

150. Arash V, Javanmard S, Eftekhari Z, Rahmati-Kamel M, Bahadoram M. Evaluation of static friction of polycrystalline ceramic brackets after conditioning with different powers of Er:YAG laser. Int $\mathrm{J}$ Dent. 2015;2015:749616. [10.1155/2015/749616]

151. Bortoly TG, Guerrero AP, Rached RN, Tanaka O, Guariza-Filho O, Rosa EA. Sliding resistance with esthetic ligatures:
An in-vitro study. Am J Orthod Dentofacial Orthop. 2008;133(3):340.e1-7.

[10.1016/j.ajodo.2007.08.015]

152. Guerrero AP, Guariza Filho O, Tanaka O, Camargo ES, Vieira S. Evaluation of frictional forces between ceramic brackets and archwires of different alloys compared with metal brackets. Braz Oral Res. 2010;24(1):40-5.

153. Lalithapriya S, Kumaran NK, Rajasigamani K. In vitro assessment of competency for different lingual brackets in sliding mechanics. J Orthod Sci. 2015;4(1):19-25. [10.4103/2278-0203.149612]

154. Wei S, Shao T. Improvement of orthodontic friction by coating archwire with carbon nitride film. Appl Surf Sci. 2011;257(24):10333-7.

[10.1016/j.apsusc.2011.06.055]

155. Thiry P, Barthelemi S. Towards slide enhancement with the titaniummolybdenum wire? Int Orthod. 2010;8(4): 319-41. [10.1016/j.ortho.2010.09.005]

156. Krishnan V, Kumar KJ. Mechanical properties and surface characteristics of three archwire alloys. Angle Orthod. 2004;74(6):825-31.

[10.1043/0003-

3219(2004)074<0825:mpasco>2.0.co;2]

157. Krishnan M, Kalathil S, Abraham KM. Comparative evaluation of frictional forces in active and passive self-ligating brackets with various archwire alloys. Am J Orthod Dentofacial Orthop. 2009;136(5):675-82 . [10.1016/j.ajodo.2007.11.034]

158. Vijayalakshmi RD, Nagachandran KS, Kummi $P$, Jayakumar P. A comparative evaluation of metallurgical properties of stainless steel and TMA archwires with timolium and titanium niobium archwires-An in vitro study. Indian $\mathrm{J}$ Dent Res. 2009;20(4):448-52.

[10.4103/0970-9290.59450]

159. Husain N, Kumar A. Frictional resistance between orthodontic brackets and archwire: An in vitro study. J Contemp Dent Pract. 2011;12(2):91-9.

160. Leander D, Kumar JK. Comparative evaluation of frictional characteristics of coated low friction ligatures - Super slick ties with conventional uncoated ligatures. Indian J Dent Res. 2011;22(1):90-4. [10.4103/0970-9290.80004]

161. Khalid SA, Kumar V, Jayaram P. The comparison of frictional resistance in titanium, self-ligating stainless steel, and 
stainless steel brackets using stainless steel and TMA archwires: An in vitro study. J Pharm Bioallied Sci. 2012; 4(Suppl 2):S203-11.

[10.4103/0975-7406.100203]

162. Jyothikiran $H$, Bansal $S$, Farhan $A$, Shivalinga B. A comparison of frictional resistance between active and passive self-ligating brackets with conventional bracket systems. World Journal of Dentistry. 2011;2(4):302-8. [10.5005/jp-journals-10015-1102]

163. Khamatkar A, Sonawane S, Narkhade S, Gadhiya N, Bagade A, Soni V, et al. Effects of different ligature materials on friction in sliding mechanics. J Int Oral Health. 2015;7(5):34-40.

164. Pasha A, Vishwakarma S, Narayan A, Vinay K, Shetty SV, Roy PP. Comparison of frictional forces generated by a new ceramic bracket with the conventional brackets using unconventional and conventional ligation system and the selfligating brackets: An in vitro study. J Int Oral Health. 2015;7(9):108-13.

165. Karim Soltani M, Golfeshan F, Alizadeh Y, Mehrzad J. Resistance to sliding in clear and metallic damon 3 and conventional edgewise brackets: An in vitro study. J Dent (Shiraz). 2015;16(1 Suppl):15-20.

166. Ho KS, West VC. Friction resistance between edgewise brackets and archwires. Aust Orthod J. 1991;12(2):95-9.

167. Tselepis M, Brockhurst P, West VC. The dynamic frictional resistance between orthodontic brackets and arch wires. Am J Orthod Dentofacial Orthop. 1994;106(2): 131-8.

168. Andreasen GF, Quevedo FR. Evaluation of friction forces in the $0.022 \times 0.028$ edgewise bracket in vitro. $\mathrm{J}$ Biomech. 1970;3(2):151-60.

169. Loftus BP, Artun J, Nicholls Jl, Alonzo TA, Stoner JA. Evaluation of friction during sliding tooth movement in various bracketarch wire combinations. Am J Orthod Dentofacial Orthop. 1999;116(3):336-45.

170. Farronato G, Maijer R, Caria MP, Esposito $L$, Alberzoni D, Cacciatore $G$. The effect of Teflon coating on the resistance to sliding of orthodontic archwires. Eur $\mathrm{J}$ Orthod. 2012;34(4):410-7. [10.1093/ejo/cjr011]

171. Inami $T$, Tanimoto $Y$, Yamaguchi $M$, Shibata Y, Nishiyama N, Kasai K. Surface topography, hardness, and frictional properties of GFRP for esthetic orthodontic wires. J Biomed Mater Res B Appl Biomater; 2015.

[10.1002/jbm.b.33372]

172. Katz A, Redlich M, Rapoport L, Wagner HD, Tenne R. Self-lubricating coatings containing fullerene-like WS 2 nanoparticles for orthodontic wires and other possible medical applications. Tribology Letters. 2006;21(2):135-9. [10.1007/s11249-006-9029-4]

173. Cha JY, Kim KS, Hwang CJ. Friction of conventional and silica-insert ceramic brackets in various bracket-wire combinations. Angle Orthod. 2007;77(1):100-7. [10.2319/092705-333r.1]

174. Kachoei M, Eskandarinejad F, Divband B, Khatamian M. The effect of zinc oxide nanoparticles deposition for friction reduction on orthodontic wires. Dent Res J. 2013;10(4):499-505.

175. Muguruma $T$, lijima $M$, Brantley WA, Ahluwalia KS, Kohda N, Mizoguchi I. Effects of third-order torque on frictional force of self-ligating brackets. Angle Orthod. 2014;84(6):1054-61.

[10.2319/111913-845.1]

176. Akaike S, Hayakawa T, Kobayashi D, Aono Y, Hirata A, Hiratsuka M, et al. Reduction in static friction by deposition of a homogeneous diamond-like carbon (DLC) coating on orthodontic brackets. Dent Mater J. 2015;34(6):888-95. [10.4012/dmj.2015-130]

177. Dickson JA, Jones SP, Davies EH. A comparison of the frictional characteristics of five initial alignment wires and stainless steel brackets at three bracket to wire angulations-- An in vitro study. $\mathrm{Br} \mathrm{J}$ Orthod. 1994;21(1):15-22.

178. Read-Ward GE, Jones SP, Davies EH. A comparison of self-ligating and conventional orthodontic bracket systems. $\mathrm{Br} \mathrm{J}$ Orthod. 1997;24(4):309-17.

179. Pizzoni L, Ravnholt G, Melsen B. Frictional forces related to self-ligating brackets. Eur J Orthod. 1998;20(3):283-91.

180. Iluru R, Nellore C, Karnati PK, Thalapaneni AK, Myla VB, Ramyasree K, et al. The effects of in-office reconditioning on the slot dimensions and static frictional resistance of stainless steel brackets. J Clin Diagn Res. 2016;10(1):Zc74-8. [10.7860/jcdr/2016/15645.7154]

181. Nishio C, da Motta AF, Elias CN, Mucha JN. In vitro evaluation of frictional forces between archwires and ceramic brackets. Am J Orthod 
Dentofacial Orthop. 2004;125(1):56-64 . [10.1016/s088954060300773x]

182. Ribeiro AA, Mattos CT, Ruellas AC, Araujo $\mathrm{MT}$, Elias CN. In vivo comparison of the friction forces in new and used brackets. Orthodontics (Chic.). 2012;13(1):e44-50.

183. Pimentel RF, de Oliveira RS, Chaves M, Elias CN, Gravina MA. Evaluation of the friction force generated by monocristalyne and policristalyne ceramic brackets in sliding mechanics. Dental Press J Orthod. 2013;18(1):121-7.

184. Yeh CL, Kusnoto B, Viana G, Evans CA, Drummond JL. In-vitro evaluation of frictional resistance between brackets with passive-ligation designs. Am J Orthod Dentofacial Orthop. 2007;131(6):704.e1122. [10.1016/j.ajodo.2006.09.041]

185. Hiroce M, Fernandes DJ, Elias CN, Miguel JA. Sliding resistance of polycarbonate self-ligating brackets and stainless steel esthetic archwires. Prog Orthod. 2012; 13(2):148-53. [10.1016/j.pio.2011.10.004]

186. Matarese $G$, Nucera $R$, Militi $A$, Mazza M, Portelli M, Festa F, et al. Evaluation of frictional forces during dental alignment: An experimental model with 3 nonleveled brackets. Am J Orthod Dentofacial Orthop. 2008;133(5):708-15.

[10.1016/j.ajodo.2006.06.021]

187. Cordasco G, Lo Giudice A, Militi A, Nucera $\mathrm{R}$, Triolo $\mathrm{G}$, Matarese $\mathrm{G}$. In vitro evaluation of resistance to sliding in self-ligating and conventional bracket systems during dental alignment. Korean $\mathrm{J}$ Orthod. 2012;42(4):218-24.

[10.4041/kjod.2012.42.4.218]

188. Nucera R, Lo Giudice A, Matarese G, Artemisia A, Bramanti E, Crupi $P$, et al. Analysis of the characteristics of slot design affecting resistance to sliding during active archwire configurations. Prog Orthod. 2013;14:35.

[10.1186/2196-1042-14-35]

189. Ireland AJ, Sherriff M, McDonald F. Effect of bracket and wire composition on frictional forces. Eur J Orthod. 1991;13(4): 322-8.

190. Sims AP, Waters NE, Birnie DJ, Pethybridge RJ. A comparison of the forces required to produce tooth movement in vitro using two self-ligating brackets and a pre-adjusted bracket employing two types of ligation. Eur $\mathrm{J}$ Orthod. 1993;15(5):377-85.

191. Sims AP, Waters NE, Birnie DJ. A comparison of the forces required to produce tooth movement ex vivo through three types of pre-adjusted brackets when subjected to determined tip or torque values. Br J Orthod. 1994;21(4):367-73.

192. Doshi UH, Bhad-Patil WA. Static frictional force and surface roughness of various bracket and wire combinations. Am J Orthod Dentofacial Orthop. 2011;139(1): 74-9. [10.1016/j.ajodo.2009.02.031]

193. Kumar BS, Miryala S, Kumar KK, Shameem K, Regalla RR. Comparative evaluation of friction resistance of titanium, stainless steel, ceramic and ceramic with metal insert brackets with varying dimensions of stainless steel wire: An in vitro multi-center study. J Int Oral Health. 2014;6(5):66-71.

194. Rudge P, Sherriff M, Bister D. A comparison of roughness parameters and friction coefficients of aesthetic archwires. Eur J Orthod. 2015;37(1):49-55.

[10.1093/ejo/cju004]

195. Grosgogeat B, Jablonska E. Tribological response of sterilized and un-sterilized orthodontic wires. Materials Science \& Engineering $\mathrm{C}$, Biomimetic and Supramolecular Systems. 2006;26(2-3):267-72. [10.1016/j.msec.2005.10.050]

196. Rapiejko C, Fouvry S, Grosgogeat B, Wendler B. A representative ex-situ fretting wear investigation of orthodontic arch-wire/ bracket contacts. Wear. 2009;266(7-8): 850-8. [10.1016/j.wear.2008.12.013]

197. Oz AA, Arici N, Arici S. The clinical and laboratory effects of bracket type during canine distalization with sliding mechanics. Angle Orthod. 2012;82(2):326-32. [10.2319/032611-215.1]

198. Huang SY, Huang JJ, Kang T, Diao DF, Duan YZ. Coating NiTi archwires with diamond-like carbon films: Reducing fluoride-induced corrosion and improving frictional properties. J Mater Sci Mater Med. 2013;24(10):2287-92.

[10.1007/s10856-013-4988-0]

199. Kang T, Huang SY, Huang JJ, Li QH, Diao DF, Duan YZ. The effects of diamond-like carbon films on fretting wear behavior of orthodontic archwire-bracket contacts. J Nanosci Nanotechnol. 2015;15(6):4641-7.

200. Seo YJ, Lim BS, Park YG, Yang IH, Ahn SJ, Kim TW, et al. Effect of tooth displacement and vibration on frictional force and stick-slip phenomenon in conventional brackets: A preliminary in vitro mechanical analysis. Eur J Orthod; 2014. [10.1093/ejo/cju027] 
Appendix I. Methodological score results of research groups' setups

\begin{tabular}{|c|c|c|c|c|c|c|c|c|c|c|c|c|c|}
\hline Research Group (RG) & $\begin{array}{l}\text { Clinical } \\
\text { Imitation? }\end{array}$ & $\begin{array}{l}\text { Reciprocal } \\
\text { Sliding? }\end{array}$ & $\begin{array}{l}\text { Labio- } \\
\text { lingual? }\end{array}$ & $\begin{array}{l}\text { Occluso- } \\
\text { apical? }\end{array}$ & Tipping? & Torque? & $\begin{array}{l}\text { Variable } \\
\text { IBD? }\end{array}$ & $\begin{array}{l}\text { Arch form } \\
\text { set? }\end{array}$ & $\begin{array}{l}\text { Oral atmo- } \\
\text { sphere? }\end{array}$ & $\begin{array}{l}\text { Variable } \\
\text { tempera- } \\
\text { ture? }\end{array}$ & $\begin{array}{l}\text { Ligature } \\
\text { materials? }\end{array}$ & $\begin{array}{l}\text { Ligation } \\
\text { force } \\
\text { applied? }\end{array}$ & Score \\
\hline I-Major RG [18] & $x$ & $x$ & $x$ & $x$ & $x$ & $x$ & $x$ & $x$ & $x$ & $x$ & $x$ & $\sqrt{2}$ & 1 \\
\hline Chang RG [65] & $\checkmark$ & $x$ & $x$ & $x$ & $x$ & $x$ & $x$ & $x$ & $x$ & $x$ & $\checkmark$ & $x$ & 2 \\
\hline Freer RG \& others $[66,67]$ & $\checkmark$ & $x$ & $x$ & $x$ & $x$ & $x$ & $x$ & $x$ & $x$ & $x$ & $\checkmark$ & $x$ & 2 \\
\hline Hooshmand RG [24] & $\checkmark$ & $x$ & $x$ & $x$ & $\mathrm{x}$ & $x$ & $x$ & $x$ & $x$ & $\mathrm{x}$ & $\checkmark$ & $x$ & 2 \\
\hline Hsu RG \& others [21,68-70] & $\checkmark$ & $x$ & $x$ & $x$ & $x$ & $x$ & $x$ & $x$ & $x$ & $x$ & $\checkmark$ & $\hat{x}$ & 2 \\
\hline I-Franchi RG [71] & $\checkmark$ & $x$ & $x$ & $x$ & $x$ & $x$ & $x$ & $x$ & $\hat{x}$ & $\hat{x}$ & $\checkmark$ & $x$ & 2 \\
\hline II-Franchi RG \& others $[72,73]$ & $\checkmark$ & $x$ & $x$ & $x$ & $x$ & $x$ & $x$ & $x$ & $x$ & $x$ & $\checkmark$ & $x$ & 2 \\
\hline II-Lin RG [74] & $\checkmark$ & $x$ & $x$ & $x$ & $x$ & $x$ & $x$ & $x$ & $x$ & $x$ & $x$ & $\checkmark$ & 2 \\
\hline I-Nanda RG\& others $[58,75,76]$ & $\checkmark$ & $x$ & $x$ & $x$ & $x$ & $x$ & $x$ & $x$ & $x$ & $x$ & $\checkmark$ & $x$ & 2 \\
\hline I-Oliveira RG $[77,78]$ & $\checkmark$ & $x$ & $x$ & $x$ & $x$ & $x$ & $x$ & $x$ & $x$ & $x$ & $\checkmark$ & $x$ & 2 \\
\hline Ireland RG [44] & $\checkmark$ & $x$ & $x$ & $x$ & $x$ & $x$ & $x$ & $x$ & $x$ & $x$ & $\checkmark$ & $x$ & 2 \\
\hline Kahlon RG \& others [45,79-83] & $\checkmark$ & $x$ & $x$ & $x$ & $x$ & $x$ & $x$ & $x$ & $x$ & $x$ & $\checkmark$ & $x$ & 2 \\
\hline Kailasam RG [84] & $\checkmark$ & $x$ & $x$ & $x$ & $\hat{x}$ & $\hat{x}$ & $\hat{x}$ & $\hat{x}$ & $\hat{x}$ & $\hat{x}$ & $\checkmark$ & $\hat{x}$ & 2 \\
\hline Kapila RG [1] & $\checkmark$ & $x$ & $x$ & $x$ & $x$ & $x$ & $x$ & $x$ & $x$ & $x$ & $\checkmark$ & $x$ & 2 \\
\hline Kim RG [85-87] & $\checkmark$ & $x$ & $x$ & $x$ & $x$ & $x$ & $x$ & $x$ & $x$ & $x$ & $\checkmark$ & $\hat{x}$ & 2 \\
\hline Lombardo RG [88] & $\checkmark$ & $x$ & $x$ & $x$ & $x$ & $\hat{x}$ & $x$ & $x$ & $\hat{x}$ & $\hat{x}$ & $\checkmark$ & $\hat{x}$ & 2 \\
\hline Mendes [43] & $\checkmark$ & $\hat{x}$ & $x$ & $x$ & $x$ & $x$ & $x$ & $x$ & $\hat{x}$ & $\hat{x}$ & $\checkmark$ & $x$ & 2 \\
\hline Taylor RG $[41,89,90]$ & $\checkmark$ & $x$ & $x$ & $x$ & $x$ & $x$ & $x$ & $x$ & $x$ & $x$ & $\checkmark$ & $x$ & 2 \\
\hline Voudouris [91] & $\checkmark$ & $x$ & $x$ & $x$ & $x$ & $x$ & $x$ & $x$ & $x$ & $x$ & $\checkmark$ & $x$ & 2 \\
\hline Basting RG \& others $[40,92,93]$ & $\checkmark$ & $x$ & $x$ & $x$ & $x$ & $x$ & $x$ & $x$ & $\checkmark$ & $x$ & $\checkmark$ & $x$ & 3 \\
\hline Berger RG $[94,95]$ & $\checkmark$ & $x$ & $x$ & $x$ & $x$ & $x$ & $x$ & $x$ & $\checkmark$ & $x$ & $\checkmark$ & $x$ & 3 \\
\hline Braun $R G[96]$ & $\checkmark$ & $x$ & $x$ & $x$ & $\checkmark$ & $x$ & $x$ & $x$ & $x$ & $x$ & $\checkmark$ & $x$ & 3 \\
\hline Dhopatkar RG \& others $[49,97-99]$ & $\checkmark$ & $x$ & $x$ & $x$ & $x$ & $x$ & $x$ & $x$ & $\checkmark$ & $x$ & $\checkmark$ & $x$ & 3 \\
\hline Khalaf RG [100] & $\checkmark$ & $x$ & $x$ & $x$ & $\checkmark$ & $x$ & $x$ & $x$ & $x$ & $x$ & $\checkmark$ & $x$ & 3 \\
\hline Khambay RG [101] & $\checkmark$ & $x$ & $x$ & $x$ & $x$ & $x$ & $x$ & $x$ & $\checkmark$ & $x$ & $\checkmark$ & $x$ & 3 \\
\hline Pliska RG [56] & $\checkmark$ & $x$ & $x$ & $x$ & $\checkmark$ & $x$ & $x$ & $x$ & $x$ & $x$ & $\checkmark$ & $x$ & 3 \\
\hline Pratten RG [102] & $\checkmark$ & $x$ & $x$ & $x$ & $x$ & $\hat{x}$ & $x$ & $x$ & $\hat{\checkmark}$ & $x$ & $x$ & $\hat{\checkmark}$ & 3 \\
\hline Stannard RG \& others $[22,38]$ & $x$ & $x$ & $x$ & $x$ & $x$ & $\hat{x}$ & $\hat{x}$ & $\hat{x}$ & $\checkmark$ & $\hat{\checkmark}$ & $\hat{x}$ & $\checkmark$ & 3 \\
\hline Suwa \& Watari RG [103] & $\checkmark$ & $x$ & $x$ & $x$ & $x$ & $x$ & $x$ & $x$ & $\checkmark$ & $x$ & $x$ & $\checkmark$ & 3 \\
\hline Tecco,Baker \&others $[42,50,104-107]$ & $\checkmark$ & $x$ & $x$ & $x$ & $x$ & $x$ & $x$ & $x$ & $\checkmark$ & $x$ & $\checkmark$ & $x$ & 3 \\
\hline Wichelhaus RG [108] & $\checkmark$ & $x$ & $x$ & $x$ & $x$ & $\checkmark$ & $x$ & $x$ & $x$ & $x$ & $\checkmark$ & $\hat{x}$ & 3 \\
\hline II-Gil RG [109] & $\checkmark$ & $x$ & $x$ & $x$ & $x$ & $x$ & $x$ & $x$ & $\checkmark$ & $x$ & $\checkmark$ & $x$ & 3 \\
\hline
\end{tabular}


Appendix I. Methodological score results of research groups' setups (Cont.)

\begin{tabular}{|c|c|c|c|c|c|c|c|c|c|c|c|c|c|}
\hline Research Group (RG) & $\begin{array}{l}\text { Clinical } \\
\text { Imitation? }\end{array}$ & $\begin{array}{l}\text { Reciprocal } \\
\text { Sliding? }\end{array}$ & $\begin{array}{l}\text { Labio- } \\
\text { lingual? }\end{array}$ & $\begin{array}{l}\text { Occluso- } \\
\text { apical? }\end{array}$ & Tipping? & Torque? & $\begin{array}{l}\text { Variable } \\
\text { IBD? }\end{array}$ & $\begin{array}{l}\text { Arch } \\
\text { form } \\
\text { set? }\end{array}$ & $\begin{array}{l}\text { Oral atmo- } \\
\text { sphere? }\end{array}$ & $\begin{array}{l}\text { Variable } \\
\text { tempera- } \\
\text { ture? }\end{array}$ & $\begin{array}{l}\text { Ligature } \\
\text { materials? }\end{array}$ & $\begin{array}{l}\text { Ligation } \\
\text { force } \\
\text { applied? }\end{array}$ & Score \\
\hline Almeida RG [110] & $\checkmark$ & $x$ & $x$ & $x$ & $\checkmark$ & $x$ & $x$ & $x$ & $x$ & $x$ & $\checkmark$ & $\times$ & 3 \\
\hline Baccetti RG\&others $[7,111]$ & $\checkmark$ & $x$ & $x$ & $\checkmark$ & $x$ & $x$ & $x$ & $x$ & $x$ & $x$ & $\checkmark$ & $x$ & 3 \\
\hline Bandeira RG [112] & $\checkmark$ & $x$ & $x$ & $x$ & $\checkmark$ & $x$ & $x$ & $x$ & $x$ & $x$ & $\checkmark$ & $x$ & 3 \\
\hline Bednar RG [55] & $\checkmark$ & $x$ & $\hat{x}$ & $\hat{x}$ & $\checkmark$ & $\hat{x}$ & $\hat{x}$ & $\hat{x}$ & $\hat{x}$ & $\hat{x}$ & $\checkmark$ & $\hat{x}$ & 3 \\
\hline Bolognese $R G$ \& others $[113,114]$ & $\checkmark$ & $x$ & $x$ & $x$ & $x$ & $x$ & $x$ & $x$ & $\checkmark$ & $x$ & $\checkmark$ & $x$ & 3 \\
\hline Brauchli RG [115] & $\checkmark$ & $x$ & $x$ & $x$ & $\checkmark$ & $x$ & $x$ & $x$ & $x$ & $x$ & $\checkmark$ & $x$ & 3 \\
\hline Cacciafesta RG [116] & $\checkmark$ & $x$ & $x$ & $x$ & $x$ & $x$ & $\checkmark$ & $x$ & $x$ & $x$ & $\checkmark$ & $x$ & 3 \\
\hline Camporesi RG [117] & $\checkmark$ & $x$ & $x$ & $\checkmark$ & $x$ & $x$ & $x$ & $x$ & $x$ & $x$ & $\checkmark$ & $x$ & 3 \\
\hline De Franco RG [118] & $\checkmark$ & $x$ & $x$ & $x$ & $\checkmark$ & $x$ & $x$ & $x$ & $x$ & $x$ & $\checkmark$ & $x$ & 3 \\
\hline Dowling RG [119] & $\checkmark$ & $x$ & $x$ & $x$ & $x$ & $x$ & $x$ & $x$ & $\checkmark$ & $\hat{x}$ & $\checkmark$ & $\hat{x}$ & 3 \\
\hline Drescher RG \& others $[3,57,120]$ & $\checkmark$ & $x$ & $x$ & $x$ & $\checkmark$ & $x$ & $x$ & $x$ & $x$ & $x$ & $\checkmark$ & $x$ & 3 \\
\hline Edwards RG [48] & $\checkmark$ & $\hat{x}$ & $\hat{x}$ & $\hat{x}$ & $x$ & $\hat{x}$ & $\hat{x}$ & $x$ & $\hat{x}$ & $\hat{x}$ & $\checkmark$ & $\hat{v}$ & 3 \\
\hline Gandedkar RG [121] & $\checkmark$ & $\checkmark$ & $x$ & $x$ & $x$ & $x$ & $\hat{x}$ & $x$ & $\hat{x}$ & $\hat{x}$ & $\checkmark$ & $x$ & 3 \\
\hline Garner RG [30] & $\checkmark$ & $x$ & $x$ & $x$ & $x$ & $x$ & $x$ & $x$ & $\checkmark$ & $x$ & $\checkmark$ & $x$ & 3 \\
\hline II-Major RG [122] & $\checkmark$ & $\hat{x}$ & $x$ & $x$ & $\checkmark$ & $x$ & $x$ & $x$ & $x$ & $x$ & $\checkmark$ & $x$ & 3 \\
\hline II-Oliveira RG [123] & $\checkmark$ & $x$ & $x$ & $x$ & $\checkmark$ & $x$ & $x$ & $x$ & $x$ & $x$ & $\checkmark$ & $x$ & 3 \\
\hline II-Redlich RG [124] & $\checkmark$ & $x$ & $\checkmark$ & $x$ & $x$ & $x$ & $x$ & $x$ & $x$ & $x$ & $\checkmark$ & $x$ & 3 \\
\hline Ioi $R G[125,126]$ & $\checkmark$ & $x$ & $x$ & $\checkmark$ & $x$ & $x$ & $x$ & $x$ & $x$ & $x$ & $\checkmark$ & $x$ & 3 \\
\hline Iwasaki RG [127] & $\checkmark$ & $x$ & $x$ & $x$ & $\checkmark$ & $x$ & $x$ & $x$ & $x$ & $x$ & $\checkmark$ & $x$ & 3 \\
\hline Jordan RG [128] & $\checkmark$ & $x$ & $x$ & $\checkmark$ & $x$ & $x$ & $x$ & $x$ & $x$ & $x$ & $\checkmark$ & $x$ & 3 \\
\hline Kuroe RG [31] & $\checkmark$ & $x$ & $x$ & $x$ & $x$ & $x$ & $x$ & $x$ & $\hat{v}$ & $\hat{x}$ & $\checkmark$ & $x$ & 3 \\
\hline Monteiro RG [129] & $\checkmark$ & $\hat{x}$ & $\hat{x}$ & $\hat{x}$ & $\hat{\checkmark}$ & $\hat{x}$ & $\hat{x}$ & $\hat{x}$ & $x$ & $\hat{x}$ & $\checkmark$ & $\hat{x}$ & 3 \\
\hline Moore RG \& others $[130,131]$ & $\checkmark$ & $x$ & $x$ & $x$ & $\checkmark$ & $\hat{x}$ & $\hat{x}$ & $\hat{x}$ & $\hat{x}$ & $\hat{x}$ & $\checkmark$ & $\hat{x}$ & 3 \\
\hline Namura RG [51] & $\checkmark$ & $\hat{x}$ & $\hat{\checkmark}$ & $\hat{x}$ & $x$ & $\hat{x}$ & $\hat{x}$ & $\hat{x}$ & $\hat{x}$ & $\hat{x}$ & $\checkmark$ & $\hat{x}$ & 3 \\
\hline Nicolls [2] & $\checkmark$ & $x$ & $x$ & $x$ & $\checkmark$ & $x$ & $x$ & $x$ & $x$ & $x$ & $\checkmark$ & $x$ & 3 \\
\hline O'Reilly RG [132] & $\checkmark$ & $x$ & $x$ & $x$ & $\checkmark$ & $x$ & $x$ & $x$ & $x$ & $x$ & $\checkmark$ & $x$ & 3 \\
\hline Oliver RG [53] & $\checkmark$ & $\hat{x}$ & $\hat{x}$ & $\hat{x}$ & $x$ & $\hat{\checkmark}$ & $\hat{x}$ & $\hat{x}$ & $\hat{x}$ & $\hat{x}$ & $\checkmark$ & $\hat{x}$ & 3 \\
\hline Ortan RG [133] & $\checkmark$ & $x$ & $x$ & $x$ & $\checkmark$ & $x$ & $x$ & $x$ & $x$ & $x$ & $\checkmark$ & $x$ & 3 \\
\hline Schumacher RG [134] & $\checkmark$ & $x$ & $x$ & $x$ & $x$ & $x$ & $x$ & $\checkmark$ & $x$ & $x$ & $\checkmark$ & $x$ & 3 \\
\hline Tanne RG [135] & $\checkmark$ & $x$ & $x$ & $x$ & $\checkmark$ & $x$ & $x$ & $x$ & $x$ & $x$ & $\checkmark$ & $x$ & 3 \\
\hline Wilmes RG [136] & $\checkmark$ & $\hat{x}$ & $\hat{x}$ & $\hat{x}$ & $\checkmark$ & $\hat{x}$ & $\hat{x}$ & $\hat{x}$ & $\hat{x}$ & $\hat{x}$ & $\checkmark$ & $\hat{x}$ & 3 \\
\hline Yamaguchi RG [137] & $\checkmark$ & $\hat{x}$ & $\hat{x}$ & $\hat{x}$ & $\checkmark$ & $\hat{x}$ & $\hat{x}$ & $\hat{x}$ & $\hat{x}$ & $\hat{x}$ & $\checkmark$ & $\hat{x}$ & 3 \\
\hline
\end{tabular}


Appendix I. Methodological score results of research groups' setups (Cont.)

\begin{tabular}{|c|c|c|c|c|c|c|c|c|c|c|c|c|c|}
\hline Research Group (RG) & $\begin{array}{l}\text { Clinical } \\
\text { Imitation? }\end{array}$ & $\begin{array}{l}\text { Reciprocal } \\
\text { Sliding? }\end{array}$ & $\begin{array}{l}\text { Labio- } \\
\text { lingual? }\end{array}$ & $\begin{array}{l}\text { Occluso- } \\
\text { apical? }\end{array}$ & Tipping? & Torque? & $\begin{array}{l}\text { Variable } \\
\text { IBD? }\end{array}$ & $\begin{array}{l}\text { Arch } \\
\text { form } \\
\text { set? }\end{array}$ & $\begin{array}{l}\text { Oral } \\
\text { atmo- } \\
\text { sphere? }\end{array}$ & $\begin{array}{l}\text { Variable } \\
\text { tempera- } \\
\text { ture? }\end{array}$ & $\begin{array}{l}\text { Ligature } \\
\text { materials? }\end{array}$ & $\begin{array}{l}\text { Ligation } \\
\text { force } \\
\text { applied? }\end{array}$ & Score \\
\hline I-Lin RG $[138,139]$ & $\checkmark$ & $x$ & $x$ & $x$ & $\checkmark$ & $x$ & $x$ & $x$ & $x$ & $x$ & $\checkmark$ & $x$ & 3 \\
\hline Pattan RG [140] & $\checkmark$ & $x$ & $x$ & $x$ & $x$ & $x$ & $\mathrm{x}$ & $x$ & $\checkmark$ & $x$ & $\checkmark$ & $x$ & 3 \\
\hline Reicheneder RG [141] & $\checkmark$ & $x$ & $x$ & $x$ & $\checkmark$ & $x$ & $\mathrm{x}$ & $x$ & $x$ & $x$ & $\checkmark$ & $x$ & 3 \\
\hline Sukh RG [25] & $\checkmark$ & $\hat{x}$ & $\hat{x}$ & $\hat{x}$ & $x$ & $\hat{x}$ & $\hat{x}$ & $\hat{v}$ & $\hat{x}$ & $\hat{x}$ & $\checkmark$ & $\hat{x}$ & 3 \\
\hline Bagby RG [142] & $\checkmark$ & $x$ & $x$ & $x$ & $x$ & $x$ & $x$ & $\checkmark$ & $\checkmark$ & $x$ & $\checkmark$ & $x$ & 4 \\
\hline Boccaccio RG [28] & $\checkmark$ & $x$ & $\checkmark$ & $\checkmark$ & $x$ & $x$ & $x$ & $x$ & $x$ & $x$ & $\checkmark$ & $x$ & 4 \\
\hline Downing RG $[143,144]$ & $\checkmark$ & $x$ & $x$ & $x$ & $x$ & $x$ & $x$ & $x$ & $\checkmark$ & $\checkmark$ & $\checkmark$ & $x$ & 4 \\
\hline II-Kusy RG [29] & $\checkmark$ & $x$ & $x$ & $x$ & $x$ & $x$ & $x$ & $\checkmark$ & $\checkmark$ & $x$ & $\checkmark$ & $x$ & 4 \\
\hline II-Nanda RG \& others $[4,145]$ & $\checkmark$ & $x$ & $\checkmark$ & $\checkmark$ & $x$ & $x$ & $x$ & $x$ & $x$ & $x$ & $\checkmark$ & $x$ & 4 \\
\hline II-Rock RG $[64,146]$ & $\checkmark$ & $x$ & $x$ & $x$ & $\checkmark$ & $\checkmark$ & $x$ & $x$ & $x$ & $x$ & $\checkmark$ & $x$ & 4 \\
\hline I-Rock RG [147] & $\checkmark$ & $x$ & $x$ & $x$ & $\checkmark$ & $\checkmark$ & $x$ & $x$ & $x$ & $x$ & $\checkmark$ & $x$ & 4 \\
\hline Lee RG [27] & $\checkmark$ & $x$ & $x$ & $\checkmark$ & $x$ & $x$ & $\checkmark$ & $x$ & $x$ & $x$ & $\checkmark$ & $x$ & 4 \\
\hline Normando RG \& others [148-150] & $\checkmark$ & $x$ & $x$ & $x$ & $\checkmark$ & $x$ & $x$ & $x$ & $\checkmark$ & $x$ & $\checkmark$ & $x$ & 4 \\
\hline Ozcan RG [39] & $\checkmark$ & $x$ & $x$ & $x$ & $x$ & $x$ & $x$ & $\checkmark$ & $\checkmark$ & $x$ & $\checkmark$ & $x$ & 4 \\
\hline Rached RG \& others [151-153] & $\checkmark$ & $x$ & $x$ & $x$ & $\checkmark$ & $x$ & $x$ & $x$ & $\checkmark$ & $x$ & $\checkmark$ & $x$ & 4 \\
\hline Shao RG [154] & $\checkmark$ & $x$ & $x$ & $x$ & $\checkmark$ & $x$ & $x$ & $x$ & $\checkmark$ & $x$ & $\checkmark$ & $x$ & 4 \\
\hline Thiry RG [155] & $\checkmark$ & $\checkmark$ & $x$ & $x$ & $x$ & $x$ & $x$ & $x$ & $\checkmark$ & $x$ & $\checkmark$ & $x$ & 4 \\
\hline Tidy RG \& others $[11,19,26,156-165]$ & $\checkmark$ & $x$ & $x$ & $x$ & $\checkmark$ & $x$ & $x$ & $x$ & $\checkmark$ & $x$ & $\checkmark$ & $x$ & 4 \\
\hline West RG \& others $[166,167]$ & $\checkmark$ & $x$ & $x$ & $x$ & $\checkmark$ & $x$ & $x$ & $x$ & $\checkmark$ & $x$ & $\checkmark$ & $x$ & 4 \\
\hline Andreasen RG [168] & $\checkmark$ & $x$ & $x$ & $x$ & $\checkmark$ & $x$ & $\checkmark$ & $x$ & $\checkmark$ & $x$ & $\checkmark$ & $x$ & 5 \\
\hline Artun RG [169] & $\checkmark$ & $x$ & $\checkmark$ & $x$ & $\checkmark$ & $x$ & $x$ & $x$ & $\checkmark$ & $x$ & $\checkmark$ & $x$ & 5 \\
\hline Farronato RG $[170,171]$ & $\checkmark$ & $x$ & $\checkmark$ & $\checkmark$ & $x$ & $\checkmark$ & $x$ & $x$ & $x$ & $x$ & $\checkmark$ & $x$ & 5 \\
\hline Frank \& Nikolai [35] & $\checkmark$ & $x$ & $x$ & $x$ & $\checkmark$ & $x$ & $\checkmark$ & $x$ & $x$ & $x$ & $\checkmark$ & $\checkmark$ & 5 \\
\hline I-Gil RG \& others $[23,60,61]$ & $\checkmark$ & $\checkmark$ & $x$ & $x$ & $\checkmark$ & $x$ & $x$ & $x$ & $\checkmark$ & $x$ & $x$ & $\checkmark$ & 5 \\
\hline I-Redlich RG\&others [20,54,172-176] & $\checkmark$ & $x$ & $x$ & $x$ & $\checkmark$ & $\hat{\checkmark}$ & $x$ & $x$ & $\checkmark$ & $x$ & $\checkmark$ & $x$ & 5 \\
\hline Jones RG\&others [62,177-180] & $\checkmark$ & $x$ & $x$ & $x$ & $\checkmark$ & $x$ & $x$ & $x$ & $\checkmark$ & $x$ & $\checkmark$ & $\checkmark$ & 5 \\
\hline Keith,Jones \&others [46,181-183] & $\checkmark$ & $x$ & $x$ & $x$ & $\checkmark$ & $x$ & $x$ & $x$ & $\checkmark$ & $x$ & $\checkmark$ & $\checkmark$ & 5 \\
\hline Kusnoto RG \&others $[184,185]$ & $\checkmark$ & $x$ & $\checkmark$ & $\checkmark$ & $x$ & $\checkmark$ & $x$ & $x$ & $x$ & $x$ & $\checkmark$ & $x$ & 5 \\
\hline Liu RG [52] & $\checkmark$ & $x$ & $x$ & $\checkmark$ & $x$ & $x$ & $x$ & $x$ & $\checkmark$ & $\checkmark$ & $\checkmark$ & $x$ & 5 \\
\hline Nucera RG [186-188] & $\checkmark$ & $x$ & $\checkmark$ & $\checkmark$ & $\checkmark$ & $x$ & $x$ & $x$ & $x$ & $x$ & $\checkmark$ & $x$ & 5 \\
\hline Sims RG\& others [189-194] & $\checkmark$ & $x$ & $x$ & $x$ & $\checkmark$ & $\checkmark$ & $x$ & $x$ & $\checkmark$ & $x$ & $\checkmark$ & $x$ & 5 \\
\hline Willems RG \& others [6,47,195-199] & $\checkmark$ & $\checkmark$ & $x$ & $x$ & $x$ & $x$ & $x$ & $x$ & $\checkmark$ & $\checkmark$ & $x$ & $\checkmark$ & 5 \\
\hline Baek RG $[8,200]$ & $\checkmark$ & $x$ & $\checkmark$ & $\checkmark$ & $x$ & $x$ & $x$ & $\checkmark$ & $\checkmark$ & $x$ & $\checkmark$ & $x$ & 6 \\
\hline I-Kusy RG \& others $[5,15-17,63]$ & $\checkmark$ & $x$ & $x$ & $x$ & $\hat{\checkmark}$ & $\hat{x}$ & $\hat{\checkmark}$ & $x$ & $\checkmark$ & $\hat{\checkmark}$ & $\checkmark$ & $\hat{\checkmark}$ & 7 \\
\hline
\end{tabular}


Appendix II. Different testing conditions of research groups' setups

\begin{tabular}{|c|c|c|c|c|c|c|c|c|c|c|}
\hline \multirow[t]{2}{*}{ Research Group (RG) } & \multirow{2}{*}{$\begin{array}{l}\text { Counter } \\
\text { Body }\end{array}$} & \multirow[t]{2}{*}{ Sliding } & \multirow{2}{*}{$\begin{array}{l}\text { Distance \&/or } \\
\text { Time }\end{array}$} & \multirow{2}{*}{$\begin{array}{l}\text { Ligation } \\
\text { Force }\end{array}$} & \multicolumn{2}{|c|}{ Inter Bracket Distance } & \multirow{2}{*}{ Temperature } & \multirow{2}{*}{ Medium } & \multirow{2}{*}{$\begin{array}{l}\text { Sliding } \\
\text { Velocity }\end{array}$} & \multirow[t]{2}{*}{ Angulation } \\
\hline & & & & & IBD & Variability & & & & \\
\hline Andreasen RG [168] & Bracket & Single-pass & Until sliding & $\begin{array}{l}\text { Spring } \\
\text { (600g) }\end{array}$ & $7 \mathrm{~mm}$ & Variable & $\mathrm{N} / \mathrm{A}$ & Dry/Saliva & $\mathrm{N} / \mathrm{A}$ & $\begin{array}{l}0^{\circ}-15^{\circ} \\
\text { (Tipping) }\end{array}$ \\
\hline Bagby RG [142] & Bracket & Single-pass & Until Sliding & $\begin{array}{l}\text { By means of } \\
\text { ligation }\end{array}$ & $\mathrm{N} / \mathrm{A}$ & Fixed & $37^{\circ} \mathrm{C}$ & $\begin{array}{l}\text { Artificial } \\
\text { Saliva }\end{array}$ & $2 \mathrm{~mm} / \mathrm{min}$ & No angulation \\
\hline Bednar RG [55] & Bracket & Single-pass & $6.35 \mathrm{~mm}$ & $\begin{array}{l}\text { By means of } \\
\text { ligation }\end{array}$ & Single Bracket & I & $\mathrm{N} / \mathrm{A}$ & Dry & $12.7 \mathrm{~mm} / \mathrm{min}$ & $100 \mathrm{~g}$ (Tip) \\
\hline Berger RG $[94,95]$ & Bracket & Single-pass & $25.4 \mathrm{~mm}$ & $\begin{array}{l}\text { By means of } \\
\text { ligation }\end{array}$ & Single Bracket & I & $\mathrm{N} / \mathrm{A}$ & Saline & $\begin{array}{l}0.025-0.5 \\
\mathrm{~mm} / \mathrm{min}\end{array}$ & No angulation \\
\hline Braun RG [96] & Bracket & Single-pass & $\mathrm{N} / \mathrm{A}$ & $\begin{array}{l}\text { By means of } \\
\text { ligation }\end{array}$ & Single Bracket & I & $\mathrm{N} / \mathrm{A}$ & Dry & $0.1 \mathrm{~mm} / \mathrm{min}$ & $\begin{array}{l}0-25.5^{\circ} \\
\text { (Tipping) }\end{array}$ \\
\hline De Franco RG [118] & Bracket & Single-pass & $3 \mathrm{~mm}$ & $\begin{array}{l}\text { By means of } \\
\text { ligation }\end{array}$ & Single Bracket & I & $\mathrm{N} / \mathrm{A}$ & Dry & $0.625 \mathrm{~mm} / \mathrm{min}$ & $\begin{array}{l}0^{\circ}-15^{\circ} \\
\text { (Tipping) }\end{array}$ \\
\hline Dowling RG [119] & Bracket & Single-pass & $\begin{array}{l}10 \text { sec after } \\
\text { sliding }\end{array}$ & $\begin{array}{l}\text { By means of } \\
\text { ligation }\end{array}$ & Single Bracket & I & $37^{\circ} \mathrm{C}$ & Wet & $1 \mathrm{~mm} / \mathrm{min}$ & No angulation \\
\hline Drescher RG \&others $[3,57,120]$ & Bracket & Single-pass & $10-12 \mathrm{~mm}$ & $\begin{array}{l}\text { Spring }(1 \mathrm{~N}) \\
\text { or by ligature }\end{array}$ & Single Bracket & I & $\mathrm{N} / \mathrm{A}$ & Dry & $\begin{array}{l}2 \mathrm{~mm} / \mathrm{sec} \text { or } 1 \\
\mathrm{~mm} / \mathrm{sec}\end{array}$ & 0 - 3 N (Tip) \\
\hline Freer RG \& others $[66,67]$ & Bracket & Single-pass & $\mathrm{N} / \mathrm{A}$ & $\begin{array}{l}\text { By means of } \\
\text { ligation }\end{array}$ & $\begin{array}{l}\text { Single Bracket or } \\
3, \mathrm{IBD}=7 \mathrm{~mm}\end{array}$ & Fixed & $\mathrm{N} / \mathrm{A}$ & $\mathrm{N} / \mathrm{A}$ & $0.01 \mathrm{~g}$ weight & No angulation \\
\hline Garner RG [30] & Bracket & Single-pass & $10 \mathrm{~mm}$ & $\begin{array}{l}\text { By means of } \\
\text { ligation }\end{array}$ & Single Bracket & 1 & $\mathrm{~N} / \mathrm{A}$ & $\begin{array}{l}\text { Artificial } \\
\text { Saliva }\end{array}$ & $2 \mathrm{~mm} / \mathrm{min}$ & No angulation \\
\hline II-Kusy RG [29] & Bracket & Single-pass & $2 \mathrm{~mm}$ & $\begin{array}{l}\text { By means of } \\
\text { ligation }\end{array}$ & $\mathrm{N} / \mathrm{A}$ & Fixed & $34^{\circ} \mathrm{C}$ & Dry/Saliva & $0.5 \mathrm{~mm} / \mathrm{min}$ & $\mathrm{N} / \mathrm{A}$ \\
\hline II-Nanda RG \& others $[4,145]$ & Bracket & Single-pass & $2 \mathrm{~min}$ or $1 \mathrm{~mm}$ & $\begin{array}{l}\text { By means of } \\
\text { ligation }\end{array}$ & $\mathrm{N} / \mathrm{A}$ & Fixed & $\mathrm{N} / \mathrm{A}$ & Dry & $\begin{array}{l}0.02 \mathrm{inch} / \mathrm{min} \\
\text { or } 0.5 \\
\mathrm{~mm} / \mathrm{min}\end{array}$ & $\begin{array}{l}\text { Horizontal/ } \\
\text { vertical up to } \\
1 \mathrm{~mm}\end{array}$ \\
\hline I-Kusy RG \& others $[5,15-17,63]$ & Bracket & Single-pass & $10-20 \mathrm{~mm}$ & $\begin{array}{l}0.05-1 \mathrm{Kg} \\
\text { or by ligature }\end{array}$ & $8-18 \mathrm{~mm}$ & Variable & $34^{\circ} \mathrm{C}$ & $\begin{array}{l}\text { Dry/Saliva } \\
\text { (different } \\
\text { viscosities) }\end{array}$ & $10 \mathrm{~mm} / \mathrm{min}$ & $\begin{array}{l}0^{\circ}-13^{\circ} \\
\text { (Tipping) }\end{array}$ \\
\hline I-Nanda RG\& others $[58,75,76]$ & Bracket & Single-pass & $2 \mathrm{~min}$ or $1 \mathrm{~mm}$ & $\begin{array}{l}\text { By means of } \\
\text { ligation }\end{array}$ & Single Bracket & 1 & $22^{\circ} \mathrm{C}$ & Dry & $\begin{array}{l}0.02 \mathrm{inch} / \mathrm{min} \\
\text { or } 12.7 \\
\mathrm{~mm} / \mathrm{min}\end{array}$ & $\begin{array}{l}\text { Self-centering } \\
\text { tip }\end{array}$ \\
\hline Jones RG\&others [62,177-180] & Bracket & Single-pass & $\begin{array}{l}0.2-8 \mathrm{~mm} \text { or } 2- \\
4 \mathrm{~min}\end{array}$ & $\begin{array}{l}100-200 \mathrm{~g} \text { or } \\
\text { ligature }\end{array}$ & Single Bracket & I & $22^{\circ} \mathrm{C}$ & $\begin{array}{l}\text { Dry/Saliva or } \\
\text { ArtSaliva }\end{array}$ & $\begin{array}{l}0.5-10 \\
\mathrm{~mm} / \mathrm{min}\end{array}$ & $\begin{array}{l}0^{\circ}-12^{\circ} \\
\text { (Tipping) }\end{array}$ \\
\hline
\end{tabular}


Appendix II. Different testing conditions of research groups' setups (cont.)

\begin{tabular}{|c|c|c|c|c|c|c|c|c|c|c|}
\hline \multirow[t]{2}{*}{ Research Group (RG) } & \multirow{2}{*}{$\begin{array}{l}\text { Counter } \\
\text { Body }\end{array}$} & \multirow[t]{2}{*}{ Sliding } & \multirow{2}{*}{$\begin{array}{l}\text { Distance \&/or } \\
\text { Time }\end{array}$} & \multirow{2}{*}{$\begin{array}{l}\text { Ligation } \\
\text { Force }\end{array}$} & \multicolumn{2}{|c|}{ Inter Bracket Distance } & \multirow[t]{2}{*}{ Temperature } & \multirow[t]{2}{*}{ Medium } & \multirow{2}{*}{$\begin{array}{l}\text { Sliding } \\
\text { Velocity }\end{array}$} & \multirow[t]{2}{*}{ Angulation } \\
\hline & & & & & IBD & Variability & & & & \\
\hline Kapila RG [1] & Bracket & Single-pass & $2 \min$ & $\begin{array}{l}\text { By means of } \\
\text { ligation }\end{array}$ & Single Bracket & 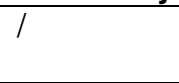 & $\mathrm{N} / \mathrm{A}$ & Dry & $5.1 \mathrm{~mm} / \mathrm{min}$ & $\begin{array}{l}\text { Self-centering } \\
\text { tip }\end{array}$ \\
\hline Keith,Jones \& others [46,181-183] & Bracket & Single-pass & $2 \mathrm{~mm}$ or $2 \mathrm{~min}$ & $\begin{array}{l}50-500 \mathrm{~g} \text { or } \\
\text { by ligatures }\end{array}$ & Single Bracket & 1 & $\mathrm{~N} / \mathrm{A}$ & Dry/Water & $\begin{array}{l}0.05,3 \text { or } 5 \\
\mathrm{~mm} / \mathrm{min}\end{array}$ & $\begin{array}{l}0^{\circ}-10^{\circ} \\
\text { (Tipping) }\end{array}$ \\
\hline Moore RG \& others $[130,131]$ & Bracket & Single-pass & Until Sliding & $\begin{array}{l}\text { By means of } \\
\text { ligation }\end{array}$ & Single Bracket & I & $\mathrm{N} / \mathrm{A}$ & $\mathrm{N} / \mathrm{A}$ & $10 \mathrm{~mm} / \mathrm{min}$ & $50-150 \mathrm{~g}$ (Tip) \\
\hline O’Reilly RG [132] & Bracket & Single-pass & $1 \mathrm{~min}$ & No & $\mathrm{N} / \mathrm{A}$ & Fixed & $\mathrm{N} / \mathrm{A}$ & $\mathrm{N} / \mathrm{A}$ & $0.5 \mathrm{~mm} / \mathrm{min}$ & $100 \mathrm{~g}$ (Tip) \\
\hline Pratten RG [102] & Bracket & Single-pass & Until sliding & $300 \mathrm{~g}$ & $10 \mathrm{~mm}$ & Fixed & $\mathrm{N} / \mathrm{A}$ & Dry/ArtSaliva & $\mathrm{N} / \mathrm{A}$ & No angulation \\
\hline Schumacher RG [134] & Bracket & Single-pass & $5 \mathrm{~mm}$ & $\begin{array}{l}\text { By means of } \\
\text { ligation }\end{array}$ & $5-8 \mathrm{~mm}$ & Fixed & $\mathrm{N} / \mathrm{A}$ & $\mathrm{N} / \mathrm{A}$ & Spring $1 \mathrm{~N}$ & No angulation \\
\hline Sims RG\& others [189-194] & Bracket & Single-pass & $\begin{array}{l}2-10 \mathrm{~min} \text { or } 5- \\
10 \mathrm{~mm}\end{array}$ & $\begin{array}{l}\text { By means of } \\
\text { ligation }\end{array}$ & $\begin{array}{l}\text { Single Bracket } \\
\text { or } 3, \mathrm{IBD}=5 \mathrm{~mm}\end{array}$ & Fixed & $24^{\circ}-37^{\circ} \mathrm{C}$ & Dry/Wet & $0.5-5 \mathrm{~mm} / \mathrm{min}$ & $\begin{array}{l}0^{\circ}-6^{\circ} \text { (Tip), } 0^{\circ}- \\
25^{\circ} \text { (Torque) }\end{array}$ \\
\hline Stannard RG \& others $[22,38]$ & $\begin{array}{l}\text { Contact } \\
\text { Flats }\end{array}$ & Single-pass & $11 \mathrm{~mm}$ & $0.2-10 \mathrm{Kg}$ & l & / & $34^{\circ} \mathrm{C}$ & Dry/ArtSaliva & $\begin{array}{l}5 \times 10^{-4}-10 \\
\mathrm{~mm} / \mathrm{min}\end{array}$ & 1 \\
\hline Tanne RG [135] & Bracket & Single-pass & $85 \mathrm{sec}$ & No & Single Bracket & / & $\mathrm{N} / \mathrm{A}$ & Dry & $0.1 \mathrm{~mm} / \mathrm{sec}$ & $\mathrm{N} / \mathrm{A}$ \\
\hline Taylor RG $[41,89,90]$ & Bracket & Single-pass & $10 \mathrm{~mm}$ & $\begin{array}{l}\text { By means of } \\
\text { ligation }\end{array}$ & $5 \mathrm{~mm}$ & $\mathrm{~N} / \mathrm{A}$ & $22^{\circ} \mathrm{C}$ & N/A & $5-10 \mathrm{~mm} / \mathrm{min}$ & No angulation \\
\hline $\begin{array}{l}\text { Tidy RG \& others }[11,19,26,156- \\
165]\end{array}$ & Bracket & Single-pass & $2-10 \mathrm{~mm}$ & $\begin{array}{l}\text { By means of } \\
\text { ligation }\end{array}$ & $8 \mathrm{~mm}$ & Fixed & $\mathrm{N} / \mathrm{A}$ & Dry/ArtSaliva & $5-10 \mathrm{~mm} / \mathrm{min}$ & $0-200 \mathrm{~g}$ (Tip) \\
\hline Voudouris [91] & Bracket & Single-pass & $8 \mathrm{~mm}$ & $\begin{array}{l}\text { By means of } \\
\text { ligation }\end{array}$ & Single Bracket & 1 & $\mathrm{~N} / \mathrm{A}$ & Dry & $10 \mathrm{~mm} / \mathrm{min}$ & No angulation \\
\hline $\begin{array}{l}\text { Willems RG \& others }[6,47,195- \\
\text { 199] }\end{array}$ & Bracket & Reciprocal & $\begin{array}{l}100-200 \mu \mathrm{m} \\
(20 \text { cycles), } 4 \\
\mathrm{mm}(1200 \\
\text { cycle) or } 0.694 \\
\mu \mathrm{m} / \mathrm{min}\end{array}$ & $1-5 \mathrm{~N}$ & Single Bracket & 1 & $20^{\circ}-37^{\circ} \mathrm{C}$ & $\begin{array}{l}\text { Humid } \\
\text { air/ArtSaliva/ } \\
\text { aq.solutions }\end{array}$ & $\begin{array}{l}0.5-5 \mathrm{~Hz} \text { or } 1 \\
\mathrm{~mm} / \mathrm{min}\end{array}$ & No angulation \\
\hline Baek RG $[8,200]$ & Bracket & Single-pass & $2.5 \mathrm{~mm}$ & $\begin{array}{l}\text { By means of } \\
\text { ligation }\end{array}$ & $\mathrm{N} / \mathrm{A}$ & Fixed & $\mathrm{N} / \mathrm{A}$ & Dry/ArtSaliva & $0.5 \mathrm{~mm} / \mathrm{min}$ & $\begin{array}{l}0-3 \mathrm{~mm} \\
\text { (vertical/lingual) }\end{array}$ \\
\hline Basting RG \& others $[40,92,93]$ & Bracket & Single-pass & $\begin{array}{l}1-10 \mathrm{~mm} \text { or } 40 \\
\mathrm{sec}\end{array}$ & $\begin{array}{l}\text { By means of } \\
\text { ligation }\end{array}$ & Single Bracket & 1 & $\mathrm{~N} / \mathrm{A}$ & $\begin{array}{l}\text { Saliva/aq } \\
\text { solutions }\end{array}$ & $3-5 \mathrm{~mm} / \mathrm{min}$ & No angulation \\
\hline Boccaccio RG [28] & Bracket & Single-pass & Until Sliding & $\begin{array}{l}\text { By means of } \\
\text { ligation }\end{array}$ & $8.5 \mathrm{~mm}$ & Fixed & $20^{\circ} \mathrm{C}$ & Dry & $\mathrm{N} / \mathrm{A}$ & $\begin{array}{l}0-4.5 \mathrm{~mm} \\
\text { (Apical \& Lab.) }\end{array}$ \\
\hline
\end{tabular}


Appendix II. Different testing conditions of research groups' setups (cont.)

\begin{tabular}{|c|c|c|c|c|c|c|c|c|c|c|}
\hline \multirow{2}{*}{ Research Group (RG) } & \multirow{2}{*}{$\begin{array}{l}\text { Counter } \\
\text { Body }\end{array}$} & \multirow{2}{*}{ Sliding } & \multirow{2}{*}{$\begin{array}{l}\text { Distance \&/or } \\
\text { Time }\end{array}$} & \multirow{2}{*}{$\begin{array}{l}\text { Ligation } \\
\text { Force }\end{array}$} & \multicolumn{2}{|c|}{ Inter Bracket Distance } & \multirow{2}{*}{ Temperature } & \multirow[t]{2}{*}{ Medium } & \multirow{2}{*}{$\begin{array}{l}\text { Sliding } \\
\text { Velocity }\end{array}$} & \multirow{2}{*}{ Angulation } \\
\hline & & & & & IBD & Variability & & & & \\
\hline Brauchli RG [115] & Bracket & Single-pass & $8 \mathrm{~mm}$ & $\begin{array}{l}\text { By means } \\
\text { of ligation }\end{array}$ & Single Bracket & l & $36^{\circ} \mathrm{C}$ & Dry & $10 \mathrm{~mm} / \mathrm{min}$ & $\begin{array}{l}0-10 \mathrm{~N} \mathrm{~mm} \\
\text { (Tip) }\end{array}$ \\
\hline Cacciafesta RG [116] & Bracket & Single-pass & $2 \min$ & $\begin{array}{l}\text { By means } \\
\text { of ligation }\end{array}$ & $20 \mathrm{~mm}$ & Variable & $\mathrm{N} / \mathrm{A}$ & Dry & $2.5 \mathrm{~mm} / \mathrm{min}$ & No angulation \\
\hline Chang RG [65] & Bracket & Single-pass & $1 \mathrm{~min}$ & $\begin{array}{l}\text { By means } \\
\text { of ligation }\end{array}$ & Single Bracket & I & $\mathrm{N} / \mathrm{A}$ & $\begin{array}{l}\text { Artificial } \\
\text { Saliva }\end{array}$ & $5 \mathrm{~mm} / \mathrm{min}$ & No angulation \\
\hline $\begin{array}{l}\text { Dhopatkar RG \& others }[49,97- \\
\text { 99] }\end{array}$ & Bracket & Single-pass & 5 or $8 \mathrm{~mm}$ & $\begin{array}{l}\text { By means } \\
\text { of ligation }\end{array}$ & Single Bracket & I & $\mathrm{N} / \mathrm{A}$ & $\begin{array}{l}\text { Dry/ Saliva/ } \\
\text { APF }\end{array}$ & $\begin{array}{l}10 \text { or } 20 \\
\mathrm{~mm} / \mathrm{min}\end{array}$ & No angulation \\
\hline Hooshmand RG [24] & Bracket & Single-pass & $5 \mathrm{~mm}$ & $\begin{array}{l}\text { By means } \\
\text { of ligation }\end{array}$ & Single Bracket & I & $\mathrm{N} / \mathrm{A}$ & Dry & $10 \mathrm{~mm} / \mathrm{min}$ & No angulation \\
\hline II-Gil RG [109] & Bracket & Single-pass & $\mathrm{N} / \mathrm{A}$ & $\begin{array}{l}\text { By means } \\
\text { of ligation }\end{array}$ & Single Bracket & I & $37^{\circ} \mathrm{C}$ & $\begin{array}{l}\text { Artificial } \\
\text { Saliva }\end{array}$ & $1 \mathrm{~mm} / \mathrm{min}$ & No angulation \\
\hline II-Redlich RG [124] & Bracket & Single-pass & $1 \mathrm{~min}$ & $\begin{array}{l}\text { By means } \\
\text { of ligation }\end{array}$ & $4.7 \mathrm{~mm}$ & Fixed & $\mathrm{N} / \mathrm{A}$ & $\mathrm{N} / \mathrm{A}$ & $5 \mathrm{~mm} / \mathrm{min}$ & $2^{\circ}-5^{\circ}($ Labial $)$ \\
\hline II-Rock RG [64,146] & Bracket & Single-pass & $7-11 \mathrm{~mm}$ & $\begin{array}{l}\text { By means } \\
\text { of ligation }\end{array}$ & Single Bracket & I & $\mathrm{N} / \mathrm{A}$ & Dry & $10 \mathrm{~mm} / \mathrm{min}$ & $\begin{array}{l}0^{\circ}-12^{\circ}(\text { Tip \& } \\
\text { Torque) }\end{array}$ \\
\hline $\begin{array}{l}\text { I-Redlich RG\&others [20,54,172- } \\
176]\end{array}$ & Bracket & Single-pass & $\begin{array}{l}5-10 \mathrm{~mm} \text { or } 25 \\
\mathrm{sec}\end{array}$ & $\begin{array}{l}\text { By means } \\
\text { of ligation }\end{array}$ & Single Bracket & I & $34^{\circ} \mathrm{C}$ & $\begin{array}{l}\text { Dry/Distilled } \\
\text { Water }\end{array}$ & $\begin{array}{l}5-20 \mathrm{~mm} / \mathrm{min} \\
\text { or } 0.5 \\
\mathrm{~mm} / \mathrm{sec}\end{array}$ & $\begin{array}{l}0^{\circ}-15^{\circ} \\
\text { (Tipping), } 0^{\circ}- \\
30^{\circ} \text { (Torque) }\end{array}$ \\
\hline Ireland RG [44] & Bracket & Single-pass & $2 \min$ & $\begin{array}{l}\text { By means } \\
\text { of ligation }\end{array}$ & $\mathrm{N} / \mathrm{A}$ & Fixed & $37^{\circ} \mathrm{C}$ & Dry/Water & $5 \mathrm{~mm} / \mathrm{min}$ & No angulation \\
\hline I-Rock RG [147] & Bracket & Single-pass & $8 \mathrm{~mm}$ & $\begin{array}{l}\text { By means } \\
\text { of ligation }\end{array}$ & Single Bracket & I & $24^{\circ} \mathrm{C}$ & $\mathrm{N} / \mathrm{A}$ & $20 \mathrm{~mm} / \mathrm{min}$ & $\begin{array}{l}1^{\circ}-3^{\circ}(\text { Tip }) \\
2^{\circ}-6^{\circ} \text { (Torque) }\end{array}$ \\
\hline Iwasaki RG [127] & Bracket & Single-pass & $10-2 \mathrm{~mm}$ & $\begin{array}{l}\text { By means } \\
\text { of ligation }\end{array}$ & Single Bracket & l & $37^{\circ} \mathrm{C}$ & $\mathrm{N} / \mathrm{A}$ & $\begin{array}{l}\text { Spring (146 } \\
\mathrm{N})\end{array}$ & $\begin{array}{l}14.6 \mathrm{~N} \mathrm{~mm} \\
\text { (Tip) }\end{array}$ \\
\hline Kailasam RG [84] & Bracket & Single-pass & $20 \mathrm{~mm}$ & $\begin{array}{l}\text { By means } \\
\text { of ligation }\end{array}$ & Single Bracket & I & $\mathrm{N} / \mathrm{A}$ & Dry & $10 \mathrm{~mm} / \mathrm{min}$ & No angulation \\
\hline Khambay RG [101] & Bracket & Single-pass & $4 \min$ & $\begin{array}{l}\text { By means } \\
\text { of ligation }\end{array}$ & Single Bracket & I & $\mathrm{N} / \mathrm{A}$ & Saliva & $5 \mathrm{~mm} / \mathrm{min}$ & No angulation \\
\hline Kim RG [85-87] & Bracket & Single-pass & $4-7 \mathrm{~mm}$ & $\begin{array}{l}\text { By means } \\
\text { of ligation }\end{array}$ & Single Bracket & l & $\mathrm{N} / \mathrm{A}$ & $\mathrm{N} / \mathrm{A}$ & $\begin{array}{l}10-12 \\
\mathrm{~mm} / \mathrm{min}\end{array}$ & No angulation \\
\hline
\end{tabular}


Appendix II. Different testing conditions of research groups' setups (cont.)

\begin{tabular}{|c|c|c|c|c|c|c|c|c|c|c|}
\hline \multirow{2}{*}{ Research Group (RG) } & \multirow{2}{*}{$\begin{array}{l}\text { Counter } \\
\text { Body }\end{array}$} & \multirow{2}{*}{ Sliding } & \multirow{2}{*}{$\begin{array}{l}\text { Distance \&/or } \\
\text { Time }\end{array}$} & \multirow{2}{*}{$\begin{array}{l}\text { Ligation } \\
\text { Force }\end{array}$} & \multicolumn{2}{|c|}{ Inter Bracket Distance } & \multirow{2}{*}{ Temperature } & \multirow{2}{*}{ Medium } & \multirow{2}{*}{$\begin{array}{l}\text { Sliding } \\
\text { Velocity }\end{array}$} & \multirow{2}{*}{ Angulation } \\
\hline & & & & & IBD & Variability & & & & \\
\hline Lee RG [27] & Bracket & Single-pass & $0.5 \mathrm{~mm}$ & No & $19 \mathrm{~mm}$ & Variable & $35^{\circ} \mathrm{C}$ & Dry & $0.05 \mathrm{~mm} / \mathrm{min}$ & $\begin{array}{l}0-4 \mathrm{~mm} \\
\text { (Apical) }\end{array}$ \\
\hline Lombardo RG [88] & Bracket & Single-pass & $\mathrm{N} / \mathrm{A}$ & $\begin{array}{l}\text { By means } \\
\text { of ligation }\end{array}$ & $\mathrm{N} / \mathrm{A}$ & Fixed & $\mathrm{N} / \mathrm{A}$ & Dry & $1 \mathrm{~mm} / \mathrm{min}$ & No angulation \\
\hline $\begin{array}{l}\text { Normando RG \& others [148- } \\
\text { 150] }\end{array}$ & Bracket & Single-pass & $5 \mathrm{~mm}$ & $\begin{array}{l}\text { By means } \\
\text { of ligation }\end{array}$ & $4-7 \mathrm{~mm}$ & Fixed & $\mathrm{N} / \mathrm{A}$ & $\begin{array}{l}\text { Dry/Artificial } \\
\text { Saliva }\end{array}$ & $0.5-5 \mathrm{~mm} / \mathrm{min}$ & $0^{\circ}-10^{\circ}$ (Tip) \\
\hline Nucera RG [186-188] & Bracket & Single-pass & $5 \mathrm{~mm}$ & $\begin{array}{l}\text { By means } \\
\text { of ligation }\end{array}$ & $8-14.5 \mathrm{~mm}$ & Fixed & $35^{\circ} \mathrm{C}$ & Dry & $4-5 \mathrm{~mm} / \mathrm{min}$ & $\begin{array}{l}\text { - } 2 \mathrm{~mm} \\
\text { (apical), } 1 \mathrm{~mm} \\
\text { (labial), } \\
0^{\circ}-13^{\circ} \\
\text { (Tipping) }\end{array}$ \\
\hline Ozcan RG [39] & Bracket & Single-pass & $5 \mathrm{~mm}$ & $\begin{array}{l}\text { By means } \\
\text { of ligation }\end{array}$ & $6 \mathrm{~mm}$ & Fixed & $20^{\circ} \mathrm{C}$ & $\begin{array}{l}\text { Artificial } \\
\text { Saliva }\end{array}$ & $20 \mathrm{~mm} / \mathrm{min}$ & No angulation \\
\hline Pliska RG [56] & Bracket & Single-pass & $\mathrm{N} / \mathrm{A}$ & $\begin{array}{l}\text { By means } \\
\text { of ligation }\end{array}$ & $10 \mathrm{~mm}$ & Fixed & $\mathrm{N} / \mathrm{A}$ & $\mathrm{N} / \mathrm{A}$ & $5 \mathrm{~mm} / \mathrm{min}$ & $\begin{array}{l}2000-4000 \\
\text { gmm (Tip) }\end{array}$ \\
\hline Rached RG \& others [151-153] & Bracket & Single-pass & $2 \min$ & $\begin{array}{l}\text { By means } \\
\text { of ligation }\end{array}$ & Single Bracket & 1 & $25^{\circ} \mathrm{C}$ & $\begin{array}{l}\text { Dry/Artificial } \\
\text { Saliva }\end{array}$ & $1-10 \mathrm{~mm} / \mathrm{min}$ & $\begin{array}{l}0^{\circ}-10^{\circ} \\
\text { (Tipping) }\end{array}$ \\
\hline Reicheneder RG [141] & Bracket & Single-pass & $10 \mathrm{~mm}$ & $\begin{array}{l}\text { By means } \\
\text { of ligation }\end{array}$ & Single Bracket & I & $\mathrm{N} / \mathrm{A}$ & $\begin{array}{l}\text { Saliva then } \\
\text { Dry }\end{array}$ & $12.7 \mathrm{~mm} / \mathrm{min}$ & $250 \mathrm{~g}$ (Tip) \\
\hline Suwa \& Watari RG [103] & Bracket & Single-pass & Until Sliding & $\begin{array}{l}1.26-4.35 \\
\mathrm{~N}\end{array}$ & Single Bracket & I & $\mathrm{N} / \mathrm{A}$ & Dry/Water & $2 \mathrm{~mm} / \mathrm{min}$ & No angulation \\
\hline $\begin{array}{l}\text { Tecco,Baker \& others } \\
{[42,50,104-107]}\end{array}$ & Bracket & Single-pass & $2-10 \mathrm{~mm}$ & $\begin{array}{l}\text { By means } \\
\text { of ligation }\end{array}$ & $5 \mathrm{~mm}$ & Fixed & $25-34^{\circ} \mathrm{C}$ & $\begin{array}{l}\text { Dry/ } \\
\text { ArtSaliva/ } \\
\text { Glycerine }\end{array}$ & $\begin{array}{l}0.5-10 \\
\mathrm{~mm} / \mathrm{min}\end{array}$ & No angulation \\
\hline Wichelhaus RG [108] & Bracket & Single-pass & $\mathrm{N} / \mathrm{A}$ & $\begin{array}{l}\text { By means } \\
\text { of ligation }\end{array}$ & Single Bracket & 1 & N/A & $\mathrm{N} / \mathrm{A}$ & $20 \mathrm{~mm} / \mathrm{min}$ & $\begin{array}{l}5 \mathrm{~N} \mathrm{~mm} \\
\text { (Torque) }\end{array}$ \\
\hline Artun RG [169] & Bracket & Single-pass & $4 \min$ & $\begin{array}{l}\text { By means } \\
\text { of ligation }\end{array}$ & Single Bracket & 1 & $\mathrm{~N} / \mathrm{A}$ & $\begin{array}{l}\text { Artificial } \\
\text { Saliva }\end{array}$ & $0.5 \mathrm{~mm} / \mathrm{min}$ & No angulation \\
\hline Baccetti RG \& others $[7,111]$ & Bracket & Single-pass & $15 \mathrm{~mm}$ & $\begin{array}{l}\text { By means } \\
\text { of ligation }\end{array}$ & $19 \mathrm{~mm}$ & Fixed & $20^{\circ} \mathrm{C}$ & Dry & $6-15 \mathrm{~mm} / \mathrm{min}$ & $\begin{array}{l}0-6 \mathrm{~mm} \\
\text { (Apical) }\end{array}$ \\
\hline Bandeira RG [112] & Bracket & Single-pass & $1 \min$ & $\begin{array}{l}\text { By means } \\
\text { of ligation }\end{array}$ & Single Bracket & I & $\mathrm{N} / \mathrm{A}$ & $\begin{array}{l}\text { Artificial } \\
\text { Saliva }\end{array}$ & $3 \mathrm{~mm} / \mathrm{min}$ & No angulation \\
\hline
\end{tabular}


Appendix II. Different testing conditions of research groups' setups (cont.)

\begin{tabular}{|c|c|c|c|c|c|c|c|c|c|c|}
\hline \multirow[t]{2}{*}{ Research Group (RG) } & \multirow{2}{*}{$\begin{array}{l}\text { Counter } \\
\text { Body }\end{array}$} & \multirow[t]{2}{*}{ Sliding } & \multirow{2}{*}{$\begin{array}{l}\text { Distance \&/or } \\
\text { Time }\end{array}$} & \multirow{2}{*}{$\begin{array}{l}\text { Ligation } \\
\text { Force }\end{array}$} & \multicolumn{2}{|c|}{ Inter Bracket Distance } & \multirow[t]{2}{*}{ Temperature } & \multirow[t]{2}{*}{ Medium } & \multirow{2}{*}{$\begin{array}{l}\text { Sliding } \\
\text { Velocity }\end{array}$} & \multirow[t]{2}{*}{ Angulation } \\
\hline & & & & & IBD & Variability & & & & \\
\hline $\begin{array}{l}\text { Bolognese RG \& others } \\
{[113,114]}\end{array}$ & Bracket & Single-pass & $5-8 \mathrm{~mm}$ & $\begin{array}{l}\text { By means of } \\
\text { ligation }\end{array}$ & Single Bracket & l & $37^{\circ} \mathrm{C}$ & Dry/ArtSaliva & $\begin{array}{l}0.5-20 \\
\mathrm{~mm} / \mathrm{min}\end{array}$ & No angulation \\
\hline Camporesi RG [117] & Bracket & Unclear & $\begin{array}{l}\text { Until Full } \\
\text { displacement }\end{array}$ & $\begin{array}{l}\text { By means of } \\
\text { ligation }\end{array}$ & $8.5 \mathrm{~mm}$ & Fixed & $20^{\circ} \mathrm{C}$ & Dry & $\mathrm{N} / \mathrm{A}$ & 0-6 mm (Apical) \\
\hline Downing RG $[143,144]$ & Bracket & Single-pass & $2 \min$ & $\begin{array}{l}\text { By means of } \\
\text { ligation }\end{array}$ & Single Bracket & 1 & $34^{\circ} \mathrm{C}$ & Dry/ArtSaliva & $5 \mathrm{~mm} / \mathrm{min}$ & No angulation \\
\hline Edwards RG [48] & Bracket & Single-pass & $1 \mathrm{~mm}$ & $100-1000 \mathrm{~g}$ & Single Bracket & 1 & $N / A$ & Dry/Saliva & $0.5 \mathrm{~mm} / \mathrm{min}$ & No angulation \\
\hline Farronato RG $[170,171]$ & Bracket & Single-pass & $2 \mathrm{~min}$ & $\begin{array}{l}\text { By means of } \\
\text { ligation }\end{array}$ & $8.5 \mathrm{~mm}$ & Fixed & $\mathrm{N} / \mathrm{A}$ & $\mathrm{N} / \mathrm{A}$ & $1-10 \mathrm{~mm} / \mathrm{min}$ & $\begin{array}{l}0-2 \mathrm{~mm} \text { (Apical), } \\
0-1 \mathrm{~mm} \text { (Ling.), } \\
0^{\circ}-10^{\circ} \text { (Torque) }\end{array}$ \\
\hline Frank \& Nikolai [35] & Bracket & Single-pass & Until Sliding & $\begin{array}{l}\text { By means of } \\
\text { ligation }\end{array}$ & $7-13 \mathrm{~mm}$ & Variable & $\mathrm{N} / \mathrm{A}$ & $\mathrm{N} / \mathrm{A}$ & $\mathrm{N} / \mathrm{A}$ & $0^{\circ}-10^{\circ}$ (Tipping) \\
\hline Gandedkar RG [121] & Bracket & Reciprocal & $\begin{array}{l}1 \mathrm{~mm}(10 \\
\text { cycles) }\end{array}$ & $\begin{array}{l}\text { By means of } \\
\text { ligation }\end{array}$ & Single Bracket & 1 & $\mathrm{~N} / \mathrm{A}$ & $\mathrm{N} / \mathrm{A}$ & $0.5 \mathrm{~mm} / \mathrm{min}$ & No angulation \\
\hline Hsu RG \& others [21,68-70] & Bracket & Single-pass & $\begin{array}{l}6-10 \mathrm{~mm} \text { or } 1- \\
2 \mathrm{~min}\end{array}$ & $\begin{array}{l}\text { By means of } \\
\text { ligation }\end{array}$ & Single Bracket & 1 & $30^{\circ} \mathrm{C}$ & Dry & $\begin{array}{l}0.5-12 \\
\mathrm{~mm} / \mathrm{min}\end{array}$ & No angulation \\
\hline I-Franchi RG [71] & Bracket & Single-pass & $12 \mathrm{~mm}$ & $\begin{array}{l}\text { By means of } \\
\text { ligation }\end{array}$ & Single Bracket & l & $20^{\circ} \mathrm{C}$ & Dry & $6 \mathrm{~mm} / \mathrm{min}$ & No angulation \\
\hline I-Gil RG \& others $[23,60,61]$ & $\begin{array}{l}\text { Disk or } \\
\text { Bracket }\end{array}$ & Rotational & $90 \mathrm{sec}$ & $1-10 \mathrm{~N}$ & $\begin{array}{l}\text { Single Bracket } \\
\text { or Disk }\end{array}$ & 1 & $37^{\circ} \mathrm{C}$ & $\begin{array}{l}\text { Dry/Artificial } \\
\text { Saliva }\end{array}$ & $\begin{array}{l}0.5236 \\
\mathrm{rad} / \mathrm{sec} \text { or } \\
18.8 \mathrm{~mm} / \mathrm{min}\end{array}$ & $0^{\circ}-5^{\circ}$ (Tipping) \\
\hline $\begin{array}{l}\text { II-Franchi RG \& others } \\
{[72,73]}\end{array}$ & Bracket & Single-pass & $2 \mathrm{~min}$ or $5 \mathrm{~mm}$ & $\begin{array}{l}\text { By means of } \\
\text { ligation }\end{array}$ & $9 \mathrm{~mm}$ & Fixed & 20 or $34^{\circ} \mathrm{C}$ & Dry & $1-20 \mathrm{~mm} / \mathrm{min}$ & No angulation \\
\hline II-Lin RG [74] & Bracket & Single-pass & $1 \mathrm{~mm}$ & $1.47 \mathrm{~N}$ & Single Bracket & 1 & $25^{\circ} \mathrm{C}$ & Dry & $6 \mathrm{~mm} / \mathrm{min}$ & No anqulation \\
\hline II-Oliveira RG [123] & Bracket & Single-pass & Until Sliding & $\begin{array}{l}\text { By means of } \\
\text { ligation }\end{array}$ & $8 \mathrm{~mm}$ & Fixed & $\mathrm{N} / \mathrm{A}$ & $\mathrm{N} / \mathrm{A}$ & $1 \mathrm{~mm} / \mathrm{min}$ & $0^{\circ}-10^{\circ}$ (Tipping) \\
\hline I-Lin RG $[138,139]$ & Bracket & Single-pass & $1 \mathrm{~min}$ & $\begin{array}{l}\text { By means of } \\
\text { ligation }\end{array}$ & $12 \mathrm{~mm}$ & Fixed & $23^{\circ} \mathrm{C}$ & Dry & $83 \mu \mathrm{m} / \mathrm{sec}$ & $0^{\circ}-23^{\circ}$ (Tipping) \\
\hline I-Major RG [18] & $\begin{array}{l}\text { Inter-wing } \\
\text { or lateral } \\
\text { surface of } \\
\text { bracket }\end{array}$ & Single-pass & $10 \mathrm{~mm}$ & $500 \mathrm{~g}$ & Single Bracket & 1 & $\mathrm{~N} / \mathrm{A}$ & Dry & $23 \mathrm{~mm} / \mathrm{min}$ & No angulation \\
\hline
\end{tabular}


Appendix II. Different testing conditions of research groups' setups (cont.)

\begin{tabular}{|c|c|c|c|c|c|c|c|c|c|c|}
\hline \multirow[t]{2}{*}{ Research Group (RG) } & \multirow{2}{*}{$\begin{array}{l}\text { Counter } \\
\text { Body }\end{array}$} & \multirow[t]{2}{*}{ Sliding } & \multirow{2}{*}{$\begin{array}{l}\text { Distance \&/or } \\
\text { Time }\end{array}$} & \multirow{2}{*}{$\begin{array}{l}\text { Ligation } \\
\text { Force }\end{array}$} & \multicolumn{2}{|c|}{ Inter Bracket Distance } & \multirow[t]{2}{*}{ Temperature } & \multirow[t]{2}{*}{ Medium } & \multirow{2}{*}{$\begin{array}{l}\text { Sliding } \\
\text { Velocity }\end{array}$} & \multirow[t]{2}{*}{ Angulation } \\
\hline & & & & & IBD & Variability & & & & \\
\hline Ioi RG $[125,126]$ & Bracket & Single-pass & $1.5-3 \mathrm{~mm}$ & $\begin{array}{l}\text { By means of } \\
\text { ligation }\end{array}$ & $4.5 \mathrm{~mm}$ & Fixed & $24^{\circ} \mathrm{C}$ & Dry & $\begin{array}{l}1 \times 10^{-5}- \\
1 \times 10^{-1} \\
\mathrm{~mm} / \mathrm{sec}\end{array}$ & 0-2 mm (Apical) \\
\hline Khalaf RG [100] & Bracket & Single-pass & Until Sliding & $\begin{array}{l}\text { By means of } \\
\text { ligation }\end{array}$ & $\mathrm{N} / \mathrm{A}$ & Fixed & $\mathrm{N} / \mathrm{A}$ & $\mathrm{N} / \mathrm{A}$ & $0.5 \mathrm{~mm} / \mathrm{min}$ & $0^{\circ}-7^{\circ}$ (Tipping) \\
\hline $\begin{array}{l}\text { Kusnoto RG \&others } \\
{[184,185]}\end{array}$ & Bracket & Single-pass & $6 \mathrm{~mm}$ & $\begin{array}{l}\text { By means of } \\
\text { ligation }\end{array}$ & $\mathrm{N} / \mathrm{A}$ & Fixed & $\mathrm{N} / \mathrm{A}$ & Dry & $\begin{array}{l}0.5-8 \\
\mathrm{~mm} / \mathrm{min}\end{array}$ & $\begin{array}{l}3^{\circ}-6^{\circ} \\
\text { (DistoPalatal), } \\
0.5-1 \mathrm{~mm} \\
\text { (intrusion), } 3^{\circ} \\
\text { (Torque) }\end{array}$ \\
\hline Namura RG [51] & Bracket & Single-pass & Until Sliding & $\begin{array}{l}\text { By means of } \\
\text { ligation }\end{array}$ & $\mathrm{N} / \mathrm{A}$ & Fixed & $\mathrm{N} / \mathrm{A}$ & Dry & $0.5 \mathrm{~mm} / \mathrm{min}$ & $\begin{array}{l}0.5-3 \mathrm{~mm} \\
\text { (Lingual) }\end{array}$ \\
\hline Nicolls [2] & Bracket & Single-pass & Until Sliding & $\begin{array}{l}\text { By means of } \\
\text { ligation }\end{array}$ & Single Bracket & l & $\mathrm{N} / \mathrm{A}$ & $\mathrm{N} / \mathrm{A}$ & $\mathrm{N} / \mathrm{A}$ & $\begin{array}{l}0^{\circ}-35^{\circ} \\
\text { (Tipping) }\end{array}$ \\
\hline Oliver RG [53] & Bracket & Single-pass & $1.5 \mathrm{~mm}$ & $\begin{array}{l}\text { By means of } \\
\text { ligation }\end{array}$ & $\mathrm{N} / \mathrm{A}$ & Fixed & $20^{\circ} \mathrm{C}$ & Dry & $1 \mathrm{~mm} / \mathrm{min}$ & $0^{\circ}-15^{\circ}$ (Torque) \\
\hline Ortan RG [133] & Bracket & Single-pass & $2 \mathrm{~mm}$ & $\begin{array}{l}\text { By means of } \\
\text { ligation }\end{array}$ & Single Bracket & l & $20^{\circ} \mathrm{C}$ & Dry & $1 \mathrm{~mm} / \mathrm{min}$ & $0^{\circ}-10^{\circ}$ (Tipping) \\
\hline Shao RG [154] & Bracket & Single-pass & $6 \mathrm{~mm}$ & $\begin{array}{l}\text { By means of } \\
\text { ligation }\end{array}$ & Single Bracket & / & $\mathrm{N} / \mathrm{A}$ & Dry/ArtSaliva & $0.1 \mathrm{~mm} / \mathrm{sec}$ & $\begin{array}{l}0^{\circ}-15^{\circ} \\
\text { (Tipping) }\end{array}$ \\
\hline Thiry RG [155] & Bracket & $\begin{array}{l}\text { Single-pass \& } \\
\text { Reciprocal }\end{array}$ & $3-5 \mathrm{~cm}$ & $\begin{array}{l}\text { By means of } \\
\text { ligation }\end{array}$ & Single Bracket & I & $\mathrm{N} / \mathrm{A}$ & $\begin{array}{l}\text { Artificial } \\
\text { Saliva }\end{array}$ & $0.1 \mathrm{~mm} / \mathrm{min}$ & No angulation \\
\hline West RG \& others $[166,167]$ & Bracket & Single-pass & $2-4 \mathrm{~mm}$ & $\begin{array}{l}\text { By means of } \\
\text { ligation }\end{array}$ & Single Bracket & l & $\mathrm{N} / \mathrm{A}$ & Dry/ArtSaliva & $10 \mathrm{~mm} / \mathrm{min}$ & $\begin{array}{l}0^{\circ}-20^{\circ} \\
\text { (Tipping) }\end{array}$ \\
\hline
\end{tabular}


Appendix II. Different testing conditions of research groups' setups (cont.)

\begin{tabular}{|c|c|c|c|c|c|c|c|c|c|c|}
\hline \multirow[t]{2}{*}{ Research Group (RG) } & \multirow{2}{*}{$\begin{array}{l}\text { Counter } \\
\text { Body }\end{array}$} & \multirow[t]{2}{*}{ Sliding } & \multirow{2}{*}{$\begin{array}{l}\text { Distance } \\
\text { \&/or Time }\end{array}$} & \multirow[t]{2}{*}{ Ligation Force } & \multicolumn{2}{|c|}{ Inter Bracket Distance } & \multirow[t]{2}{*}{ Temperature } & \multirow[t]{2}{*}{ Medium } & \multirow{2}{*}{$\begin{array}{l}\text { Sliding } \\
\text { Velocity }\end{array}$} & \multirow[t]{2}{*}{ Angulation } \\
\hline & & & & & IBD & Variability & & & & \\
\hline Almeida RG [110] & Bracket & Single-pass & $10 \mathrm{~mm}$ & By means of ligation & Single Bracket & 1 & $\mathrm{~N} / \mathrm{A}$ & $\mathrm{N} / \mathrm{A}$ & $5 \mathrm{~mm} / \mathrm{min}$ & $0^{\circ}-5^{\circ}$ (Tipping) \\
\hline II-Major RG [122] & Bracket & Single-pass & $0.2 \mathrm{~mm}$ & By means of ligation & Single Bracket & 1 & $\mathrm{~N} / \mathrm{A}$ & $\mathrm{N} / \mathrm{A}$ & $0.05 \mathrm{~mm} / \mathrm{sec}$ & $0^{\circ}-6^{\circ}$ (Tipping) \\
\hline I-Oliveira RG $[77,78]$ & Bracket & Single-pass & $9 \mathrm{~mm}$ & By means of ligation & $\mathrm{N} / \mathrm{A}$ & Fixed & $20^{\circ} \mathrm{C}$ & Dry & $0.075 \mathrm{~mm} / \mathrm{seg}$ & No angulation \\
\hline Jordan RG [128] & Bracket & Single-pass & $4 \mathrm{~mm}$ & By means of ligation & $6 \mathrm{~mm}$ & Fixed & $24^{\circ} \mathrm{C}$ & Dry & $2 \mathrm{~mm} / \mathrm{min}$ & $0^{\circ}-12^{\circ}$ (Apical) \\
\hline $\begin{array}{l}\text { Kahlon RG \& others [45,79- } \\
\text { 83] }\end{array}$ & Bracket & Single-pass & $\begin{array}{l}1 \mathrm{~min} \text { or } 10 \\
\mathrm{~mm}\end{array}$ & By means of ligation & $5,7.5$ or $10 \mathrm{~mm}$ & Fixed & $20^{\circ} \mathrm{C}$ & Dry & $\begin{array}{l}0.5-6 \mathrm{~mm} / \mathrm{min} \text { or } \\
2 \mathrm{~mm} / \mathrm{sec}\end{array}$ & No angulation \\
\hline Kuroe RG [31] & Bracket & Single-pass & Until Sliding & By means of ligation & Single Bracket & 1 & $15^{\circ} \mathrm{C}$ & Humid Air & $6 \mathrm{~mm} / \mathrm{min}$ & No angulation \\
\hline Liu RG [52] & Bracket & Single-pass & $3 \mathrm{~mm}$ & By means of ligation & $\mathrm{N} / \mathrm{A}$ & Fixed & $20^{\circ}-55^{\circ} \mathrm{C}$ & $\begin{array}{l}\text { Artificial } \\
\text { Saliva }\end{array}$ & $0.5 \mathrm{~mm} / \mathrm{min}$ & 0-3 mm (Apical) \\
\hline Mendes [43] & Bracket & Single-pass & $9 \mathrm{~mm}$ & By means of ligation & Single Bracket & 1 & $\mathrm{~N} / \mathrm{A}$ & Dry & $5 \mathrm{~mm} / \mathrm{min}$ & No angulation \\
\hline Monteiro RG [129] & Bracket & Single-pass & $2 \mathrm{~mm}$ & By means of ligation & Single Bracket & I & $20^{\circ} \mathrm{C}$ & Dry & $3 \mathrm{~mm} / \mathrm{min}$ & $\begin{array}{l}0^{\circ}-10^{\circ} \\
\text { (Tipping) }\end{array}$ \\
\hline Pattan RG [140] & Bracket & Single-pass & $\begin{array}{l}20 \mathrm{~mm} \text { after } \\
\text { peak }\end{array}$ & By means of ligation & Single Bracket & l & $\mathrm{N} / \mathrm{A}$ & Saliva & $5 \mathrm{~mm} / \mathrm{min}$ & No angulation \\
\hline Sukh RG [25] & Bracket & Single-pass & $7.5 \mathrm{~mm}$ & By means of ligation & $\mathrm{N} / \mathrm{A}$ & Fixed & $\mathrm{N} / \mathrm{A}$ & Dry & $0.5 \mathrm{~mm} / \mathrm{min}$ & No angulation \\
\hline Yamaguchi RG [137] & Bracket & Single-pass & $2 \mathrm{~mm}$ & By means of ligation & Single Bracket & 1 & $\mathrm{~N} / \mathrm{A}$ & $\mathrm{N} / \mathrm{A}$ & $0.1 \mathrm{~mm} / \mathrm{sec}$ & $\begin{array}{l}100-400 \mathrm{~g} \\
\text { (Tip) }\end{array}$ \\
\hline Wilmes RG [136] & Bracket & Single-pass & $70 \mathrm{~mm}$ & By means of ligation & Single Bracket & 1 & $\mathrm{~N} / \mathrm{A}$ & $\mathrm{N} / \mathrm{A}$ & $1 \mathrm{~mm} / \mathrm{sec}$ & $10 \mathrm{~N} \mathrm{~mm}$ (Tip) \\
\hline
\end{tabular}

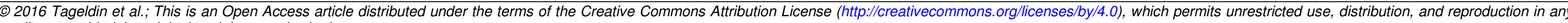
medium, provided the original work is properly cited.

Peer-review history:

The peer review history for this paper can be accessed here:

http://sciencedomain.org/review-history/15531 